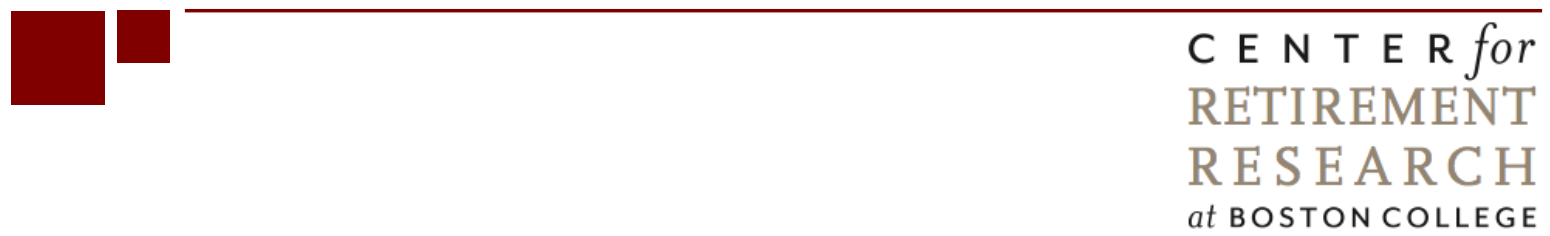

\title{
GROWTH IN HEALTH CONSUMPTION AND ITS IMPLICATIONS FOR FINANCING OASDI: AN INTERNATIONAL PERSPECTIVE
}

\author{
Barry P. Bosworth and Gary Burtless
}

CRR WP 2012-21

Submitted: August 2012

Released: September 2012

\author{
Center for Retirement Research at Boston College \\ Hovey House \\ 140 Commonwealth Avenue \\ Chestnut Hill, MA 02467 \\ Tel: 617-552-1762 Fax: 617-552-0191 \\ http://crr.bc.edu
}

Barry P. Bosworth is a senior fellow at the Brooking Institution. Gary Burtless holds the John C. and Nancy D. Whitehead Chair in Economic Studies at the Brookings Institution. The research reported here was performed pursuant to a grant from the U.S. Social Security Administration (SSA) funded as part of the Retirement Research Consortium (RRC). The opinions and conclusion expressed are solely those of the authors and do not represent the opinions or policy of SSA, any agency of the federal government, the RRC, the Brookings Institution, or Boston College.

(C) 2012, by Barry P. Bosworth and Gary Burtless. All rights reserved. Short sections of text, not to exceed two paragraphs, may be quoted without explicit permission provided that full credit, including (C) notice, is given to the source. 


\section{About the Center for Retirement Research}

The Center for Retirement Research at Boston College, part of a consortium that includes parallel centers at the University of Michigan and the National Bureau of Economic Research, was established in 1998 through a grant from the Social Security Administration. The Center's mission is to produce first-class research and forge a strong link between the academic community and decision-makers in the public and private sectors around an issue of critical importance to the nation's future. To achieve this mission, the Center sponsors a wide variety of research projects, transmits new findings to a broad audience, trains new scholars, and broadens access to valuable data sources.

Center for Retirement Research at Boston College

Hovey House

140 Commonwealth Avenue

Chestnut Hill, MA 02467

phone: 617-552-1762 fax: 617-552-0191

e-mail:crr@bc.edu

crr.bc.edu

Affiliated Institutions:

The Brookings Institution

Massachusetts Institute of Technology

Syracuse University

Urban Institute 


\begin{abstract}
The rising cost of U.S. health care has reduced the share of compensation that is taxable by Social Security. Between 1960 and 2010, non-taxable employer premiums for worker health plans increased from 1 percent of employee compensation to 7 percent. We use international data to examine the determinants of trends in health care spending and the reasons that the U.S. experience has differed from that of other high-income countries. In 2010, the share of U.S. gross domestic product devoted to health care was 7.2 percentage points higher than the share in other rich countries. We document the growth of this gap in the past five decades. Much of it developed between 1980 and the mid-1990s, though we also find another episode of outsized growth in the early 2000s. We identify six countries, including most of Scandinavia, which have seen a slowdown in health spending growth. These were also countries that had higher-thanexpected health spending, given their average incomes, in the 1960s and 1970s. The slowdown in health expenditure growth may simply reflect a reversion of their spending toward the OECD mean. We find no mean reversion in U.S. health spending growth. Our review of other literature suggests that the current excess in U.S. health costs is mainly traceable to higher prices for health care goods and services. Compared with other OECD countries, the United States has been slow to develop institutions or global budget constraints that restrain the pace of growth in health costs.
\end{abstract}




\section{Introduction}

For more than a quarter century, the Social Security program has faced worsening longrun financial prospects. The estimated actuarial balance has declined from a small surplus in the immediate aftermath of the 1983 reforms to a deficit that is now estimated to be 2.7 percent of taxable payroll (about 1 percent of gross domestic product). Much of this deterioration can be traced to the increased benefit costs of an aging population and the inclusion of additional years in the projection period in which expected outlays will far outstrip predicted revenue. The program has also been adversely affected on the revenue side by a steady deterioration in taxable wages as a share of both GDP and labor compensation. Since the last major reforms, in 1983, the share of taxable wages in GDP has fallen by 6 percentage points, to 35 percent of GDP from 42 percent (Figure 1). The fall can be attributed to several factors. The first and most important is a shift of aggregate income away from labor and to corporate profits and other forms of capital income. However, the tax base has also fallen as a proportion of labor compensation. Since 1983, the ratio of taxable wages to employee compensation has dropped by 7 percentage points. First, there has been a large shift in the distribution of wage income toward workers whose earnings exceed the taxable wage ceiling (currently $\$ 110,000$ ). Second, the rate of growth of employer payments for health insurance, which are excluded from the tax base, has far exceeded the rate of increase in earnings. In the national income and product accounts (NIPA), the sum of employer premium payments for employee group health plans increased from 1.1 percent of total compensation in 1960 to 4.5 percent in the mid-1980s and to 7 percent of compensation in 2010 (Figure 2). ${ }^{1}$ It is also evident that, although much of health care is a private-sector cost, its growth makes it an important funding competitor with Social Security, complicating efforts to resolve the retirement system's future financial problems.

This paper examines the underlying determinants of national trends in health care spending and the reasons that the U.S. experience has differed so dramatically from that of other high-income countries. The United States spends a far larger share of its resources on health care -18 percent of GDP in 2010 - compared with other rich countries, yet health outcomes are

\footnotetext{
${ }^{1}$ In addition, the employer portion of the Medicare tax (1.45 percent of earnings) is also excluded from the OASDI tax base.
} 
equivalent to or worse than outcomes in other countries. The goal of the study is to see whether there are lessons from other rich countries' experiences that would guide Social Security trustees in projecting trends in health care spending and in anticipating a future year in which the excess of spending growth above national income growth will end.

We first estimate the share of U.S. health spending that exceeds what would be predicted based on spending patterns in other rich countries. We also estimate the growth in this excess spending over time. The outsized growth of U.S. health spending appears to have been concentrated in the decade and a half after 1979. During the past half decade, the pace of U.S. spending growth does not appear to be out of line with that in other rich countries. In the following section we attempt to identify countries that have seen a slowdown in the growth of their health spending relative to their GDP. Do these countries offer any lessons about the factors or policies that can produce such a slowdown? Our estimates suggest that countries that have seen trend declines in spending growth over the past half century are countries that tended to spend more, given their income levels, at the start of the period. We conclude the paper with a discussion of the factors that may explain the large excess of health spending in the United States relative to other countries.

\section{Estimating Excess U.S. Health Spending}

In an international comparison with other high-income countries, the United States is an extreme outlier both in terms of the share of its GDP devoted to health care and the absolute level of per capita spending on health care. OECD data on health expenditures suggest the share of GDP devoted to health spending in the United States was about 40 percent higher than the average for the other OECD countries in the 1970s. As shown in Figure 3, the differential increased substantially during the 1980s and then slowly widened in later decades. By 2010 the U.S. health share was almost 70 percent (or 7.2 percentage points of GDP) larger than the health spending share in the same set of countries. In 2010, the United States spent about $\$ 7,500$ per capita on health care, compared to an average of $\$ 3,300$ in the other countries.

To derive the estimates in Figure 3 we use the most recent OECD estimates of total health expenditures for a sample of 20 high-income countries. (Among the large OECD countries, only Italy is excluded from the comparison because Italian health spending data do not begin until 1988.) The national-level OECD estimates are converted into international dollars 
using estimates of purchasing power parity (PPP) exchange rates, and total health spending in the 19 non-U.S. countries is then divided by the sum of the GDPs in the 19 countries, which are also measured in international dollars using PPP exchange rates. In 1970 the United States allocated 7.1 percent of its GDP to health care, 2.1 percentage points more than the weighted average health spending of the other 19 countries. Since 1970, the share of U.S. GDP devoted to health spending has increased about 0.26 percentage points a year. In the other OECD countries, health spending as a share of GDP has increased about 0.12 percentage points per year. As already noted, by 2010 we estimate that the spending gap had risen to 7.2 percentage points of GDP. If the United States had allocated the same proportion of GDP to health spending as the other 19 countries, American health expenditures would have been lower by about $\$ 1.05$ trillion, or 40 percent.

That estimate of excess health spending assumes that wealthy OECD countries can be expected to devote approximately equal proportions of output to their health care systems. This is unlikely to be true for a number of reasons. Some countries may have older or less healthy populations, which require greater health services. Others may prefer health consumption to other kinds of consumption. In fact, however, the differences in the ratio of health spending to GDP are comparatively small among the other rich countries in our sample. The OECD has estimates of 2009 health spending for all 21 countries in our sample. If the United States is excluded from the comparison, the nation with the highest proportional health spending in 2009 was the Netherlands, which devoted 11.9 percent of its GDP to health care. The nation devoting the smallest fraction of income to health care was Australia, which spent 9.1 percent of its GDP on health. The gap between the lowest spending and highest spending country, excluding the United States, was thus 2.8 percent of GDP. In 2009, the United States devoted 17.7 percent of its GDP to health care, 5.8 percentage points more than the second highest spending country, the Netherlands, and 7.4 percentage points more than the median non-U.S. country in the sample.

One partial explanation for higher spending in the United States is higher income. Depending on the measure of purchasing power parity used, in 2009 the United States had an average income level that was between one-quarter and one-third higher than that of the median country in the comparison group. If the share of income devoted to health consumption increases with average income, we would expect the United States to spend a higher proportion of its income on health compared with other OECD member countries. Indeed, there was a 
positive correlation in 2009 between countries' average incomes and the share of their GDP devoted to health care. Most of the correlation, however, is due to the United States. The correlation between average income and percent of GDP devoted to health care is small in the other 20 countries in the sample.

Figure 4 shows estimates of the relationship between health care spending per capita and GDP per capita in a small sample of countries. The chart has four panels, which present OLS estimates of the health spending--income relationship in four years: 1960, 1975, 1990, and 2009. The four panels show health spending and GDP per capita for 10 of the 21 countries in our sample: Australia, Austria, Canada, Finland, France, Japan, Norway, Spain, the United Kingdom, and the United States. Incomes and health spending for each country are converted into constant U.S. dollars using purchasing power parity estimates for 2005 published by the OECD. The sample of countries is determined by the availability of PPP estimates of GDP per capita, published by the OECD, and estimates of the share of GDP devoted to health, which are also published by the OECD. For each year displayed in Figure 4, we estimated a simple crossnational equation:

$$
\operatorname{Ln}(\mathrm{H})=\alpha+\beta \operatorname{Ln}(\mathrm{Y})
$$

where

$\mathrm{H}=$ Health spending per capita, measured in constant U.S. dollars at PPP exchange rates; $\mathrm{Y}=$ GDP per capita, measured in constant U.S. dollars at PPP exchange rates.

The equation was first estimated with all 10 countries in the sample, including the United States. It was then re-estimated without the United States. The results of the first set of estimates are displayed as solid lines in each panel, while the results from the second are displayed as broken lines. Note that the exclusion of the United States from the estimation sample in 1960 has little impact on the regression line. U.S. spending on health care is close to the level that would be predicted based on the cross-national relationship between spending and GDP per capita observed in the other nine countries. By 1975, U.S. health spending was slightly higher than predicted given its income and the relationship between health spending and income in the other nine countries. The gap widened considerably by 1990, when U.S. health spending 
(measured in 2005 dollars) was nearly $\$ 4,000$ per person. This amount is about $\$ 1,000$ (32 percent) more than would be predicted by a regression that includes the United States, and it is almost $\$ 1,400$ (54 percent) greater than predicted by a regression that excludes the United States. The absolute size of the prediction error is even greater in 2009 , and the proportional gap between U.S. spending and the amount of spending predicted on the basis of the other countries' experiences grows as well, reaching 75 percent. Note in the third and fourth panels of Figure 4 that the United States has a noticeable impact on the regression line when it is included in the estimation.

In Figure 5, we summarize the estimates of the income elasticity of health spending that are derived from this panel of 10 countries. We show estimates for all the years between 1960 and 2009 when PPP income and health spending data are available from the OECD to estimate the proportion of national income devoted to health expenditures. The chart shows two sets of estimates, one based on the complete panel of countries, including the United States, and the second based on the nine non-U.S. countries. Note that the estimated income elasticity of health spending has declined from about 1.7 in 1960 to between 1.0 and 1.5 in recent years. The lower estimate is based on the cross-national distribution of health spending and average income among the non-U.S. countries. The higher estimate reflects the spending pattern in the United States as well as the other nine countries.

Another way to use the results is to derive an estimate of the U.S. health spending gap compared with spending levels in the other nine countries of the panel. Figure 6 shows two sets of point estimates of the gap. The smaller estimate is based on a prediction of health spending derived from the combined experiences of all ten sample countries, including the United States. The higher estimate is based on a prediction of expected U.S. spending derived solely from the estimated relationship between health spending and income in the non-U.S. countries. Both sets of estimates suggest U.S. health spending, adjusting for national income, strongly outpaced spending growth in the other nine countries between 1960 and the early 1990s. Since the early 1990s, however, U.S. spending growth has fluctuated relative to the growth that would be predicted based on patterns in the other nine countries in the sample.

Alternative Estimates. The estimates in the previous section highlight findings that rely on cross-national spending differences at a given point in time within a small and fixed sample of 
countries. The income and spending differences between the countries rely upon a single measure of PPP exchange rates, published by the OECD. There are alternative measures of PPP exchange rates that cover the period we are interested in. For example, the Penn World Tables (Heston, Summers, and Aten 2011) and the U.S. Bureau of Labor Statistics (2011) have published estimates of GDP per capita using alternative methods for calculating PPP exchange rates.

Alternative currency conversion estimates can produce differences in relative incomes in OECD member countries, as a simple example will show. All three sets of PPP estimates just mentioned agree that real Australian incomes have increased compared with those in the United States since the early 1990s. However, the Penn Word Table (2005 \$) conversion factors show a faster relative income improvement over time. By 2009 they imply that Australia's per capita GDP was approximately equal to U.S. per capita GDP. In contrast, the OECD (2005 \$) and BLS (2010 \$) estimates indicate that by 2009 Australia's real average income was still about 15 percent below average U.S. income. Obviously, estimates of the income elasticity of health spending that rely on cross-national estimates of income and health spending may be sensitive to currency conversion differences that are this large. Another reason for different estimates of GDP per capita is that statistical agencies may rely on national statistical agency data of different vintages. GDP and population estimates are subject to periodic revisions, and the statistical agency calculating cross-national per capita GDP statistics may use national statistical estimates that are already out of date when the cross-national statistics are published.

The alternative estimates of PPP conversion factors and per capita GDP make it hard to argue that any single statistical study of the relationship of health spending to national income produces definitive results. Instead, we believe it is worthwhile to use alternative sets of PPP conversion factors to see which conclusions about the trend in national health care costs are most robust to the use of alternative PPP estimates. Although there is a common, OECD-provided set of estimates of the proportion of national GDP devoted to health spending, there are a variety of estimates of relative GDP per capita. Moreover, some of the available alternatives do not provide estimates of GDP for the full complement of countries or calendar years for which the OECD offers health spending data. The data points displayed in Figures 5 and 6 show results for only 24 of the 51 years between 1960 and 2010 because those are the only 24 years for which the 10 countries included in the charts all supplied health spending data to the OECD and had PPP 
estimates of GDP in the OECD data bank. In the other 27 years, at least one critical item for our estimates was missing for at least one of the countries. In the interest of estimating the relationship between health spending and income for the longest possible span of years and for a consistent set of countries, analysts are forced to restrict their samples to a small number of countries and a modest set of years.

Another way to estimate excess health spending in the United States is to use information for a heterogeneous set of countries in successive years, maximizing both the number of countries that can be included in the analysis and the number of years of valid national data used to evaluate cross-national patterns of health spending growth. The three panels in Figure 7 show such estimates for the period 1960-2010. Each panel contains information from the full or a partial complement of the 21 OECD countries in our sample, with a majority of countries providing information for only a subset of years. The results in each panel were derived using an alternative set of estimates of PPP exchange rates. (The availability of data, by country and estimated PPP exchange rate, is displayed in an appendix table.) For example, the first panel of Figure 7 shows estimates of excess U.S. spending when the OECD's PPP exchange rates are applied for those countries with an estimated PPP exchange rate and OECD estimate of health spending in the indicated year. Each panel displays two estimates of excess U.S. health spending. The first and smaller measure is the estimated residual from equation (1) when the annual regression is estimated using all the countries supplying data for the year, including the United States. The second is the estimated residual when the regression is estimated solely with the non-U.S. countries in the sample.

Notwithstanding the differences in PPP exchange rates and the collection of countries supplying data for the estimates, there are close similarities in the estimated pattern of excess U.S. health spending growth. All three panels show that, controlling for income differences, U.S. health spending was about 15 percent to 20 percent above the level that would be predicted based on other countries' spending patterns in the 1970s. Starting in 1979 there was a sizeable upward shift in U.S. spending, one that ended in the early 1990s. Between the late 1970s and early 1990s, excess U.S. health spending increased from about 20 percent to about 60 percent above the level that would be predicted based on other countries' spending patterns. The first decade of the $21^{\text {st }}$ century saw another upward drift in relative U.S. spending levels, with the estimated prediction error rising to about 70 percent of the spending level that would be expected 
given the U.S. income level and the cross-sectional pattern of spending in other OECD countries. In estimates not shown here, we obtained similar results based on a linear specification of the relation between average health spending and average national income. The estimates show a nearly identical pattern in the timing of growth and the proportional size of the growth in excess U.S. health spending.

For each set of estimates of PPP exchange rates it is possible to identify groups of countries that provide consistent information about income and health spending trends for select years over a long a long time span. These kinds of estimates, similar to those displayed in Figure 6 , are not affected by changes in the composition of the included countries from one year to the next. Like the estimates displayed in Figure 6, the findings from these statistical analyses (not reported here) show a pattern of growth in excess U.S. health spending that is very close to that described in the previous paragraph and displayed in Figure 7. The timing and scale of the upward shift in U.S. health spending is very similar in all the analyses. Thus, our estimates of the timing and scope of excess spending growth in the United States are robust to different estimates of PPP exchange rates, to the inclusion of different sets of comparison countries in the statistical analysis, and to alternative functional specifications of the relationship between average health spending and average income levels.

\section{Can We Identify Countries with Slow Spending Growth?}

All estimates discussed so far show a clear pattern of outsized growth in U.S. health care spending. We tried to identify countries with unusually slow spending growth using similar methods. To do this, we estimated cross-national health spending patterns for successive years under all three estimates of PPP exchange rates and for a variety of country groupings under each of the three sets of PPPs. Our initial estimates for each set of PPP exchange rates were based on the full sample of countries for which PPP exchange rates were available (see the appendix table). Those estimates are the source of the excess U.S. spending results reported in Figure 7. The advantage of these estimates is that we can obtain an estimate of a nation's excess or shortfall in health spending for each year it supplies health expenditure estimates to the OECD and has a reported PPP exchange rate. The disadvantage of this approach is that each year's estimate of a country's spending excess or shortfall may be based on spending patterns in a shifting comparison set of countries. For example, a number of European countries began to 
supply health expenditure data to the OECD in the early 1970s. Before that year, those countries' health spending information was not available to estimate the determinants of crossnational patterns of health spending. The apparent performance of a country that provided continuous health expenditure data before and after the early 1970s could be affected by the spending characteristics of the new countries entering the sample in the early 1970s.

To avoid this problem we created consistent groupings of OECD member countries which supplied required data for each year used in our analysis. The appendix table shows the tradeoff between including a large number of countries in the analysis and obtaining estimates for a long span of years. Using the OECD estimates of PPPs, only 8 countries among the 21 in our sample have both health and per capita GDP information for at least 50 years. Using the Penn World Table PPP estimates, only 10 of the 21 countries have complete data covering at least 50 years. Including more countries in a consistent country sample requires us to give up years in the estimation. To deal with this issue we created three consistent country-year samples for each alternative PPP series. The first and narrowest sample consisted solely of the countries supplying information for at least 50 years. The second and larger sample consisted of most or all countries that began to supply health spending data in the early 1960s, even if there were interruptions in a nation's data in later years. The third and largest consistent sample was composed of countries for which reasonably good data begin to be available no later than the mid-1970s. Thus, our data analysis examined three alternative estimates of PPP exchange rates and, for each exchange rate series, obtained estimates for four groupings of countries. The first consists of all countries among the 21 who supplied any usable data; the other three are the subsamples of countries providing usable data for increasing spans of years.

Our estimate of a country's excess or shortfall of spending in a given year is the estimated deviation from the regression line that is determined by the other countries in the sample in that year. Since we are interested in the trend in the residual, we estimated a sequence of regressions of the form

$$
\operatorname{Ln}\left(H_{i t}\right)=\alpha_{t}+\beta_{t} \operatorname{Ln}\left(Y_{i t}\right)+\gamma C_{i}+\partial_{i}\left(C_{i} \cdot t\right)+\varepsilon_{i t}
$$

where

$\mathrm{C}_{\mathrm{i}}=$ Indicator variable for country $i$. 
We estimated models that included and excluded observations from the United States. Because the rankings of low-spending countries did not appear sensitive to this choice, our discussion in the remainder of the section focuses on estimates that exclude the United States. We also estimated the health spending-income relationship in a linear as well as a logarithmic form. Again, this choice did not noticeably affect the identification of low-spending countries, so we will only discuss the results of our logarithmic specification here. In identifying lowspending countries we are looking for countries that have moved in the opposite direction from the United States. The estimates in the previous section suggest that the United States was an average or only moderately above average spender in the $1960 \mathrm{~s}$, but became a massive overspender in the decade and a half after 1979. Are there any countries that made the reverse trip? Controlling for national income, can we identify any countries that moved down the spending league tables?

Table 1 presents our estimates of the coefficients $\partial_{i}$. The table contains four panels. The top panel contains our estimates based on the all-country, all-year sample. The panel immediately below shows estimates from our most restrictive consistent samples, in particular, for countries that provided continuous useable data from 1960 through 2009 or 2010 . The third panel displays estimates from consistent samples of countries that provided at least some data from the 1960s, even if the data were not continuously available. The last panel shows results from our largest consistent samples, countries that provided data starting no later than the mid1970s. Note that each of the last three (or consistent) samples includes only information for a given calendar year if each country in the sample has usable data for the year. Each panel contains three sets of columns. The columns on the left show results based on the Penn World Table (2011) estimates of GDP per capita at PPP exchange rates (2005 \$). The middle columns are based on estimates using the OECD (2012) estimates of GDP per capita (2005 \$); and the columns on the right are based on results using the BLS (2011) estimates of GDP per capita (2010 \$). Within each set of a panel's columns, we have ranked countries by the estimated trend decline in the country's health spending conditional on its income level. P-values are calculated against the null hypothesis that the trend decline is zero. In the top panel of Table 1, for example, Sweden is shown to have a strong and significant decline in health spending per person, given the trend in its relative income and compared to the health spending in the other countries in the samples. Furthermore, the downward trend in Swedish spending is apparent for 
all estimates of PPP conversion factors and within each sample where it is possible to measure the relative trend in Swedish health care spending.

In addition to Sweden, our results also suggest that Canada, Denmark, Finland, Ireland, and Japan saw declines in their health care spending relative to the spending that would be predicted from the experience of other OECD countries. Note that these countries may have health spending that exceeds the level that would be predicted based on the estimated elasticity of health spending in the other countries of the sample. Our estimates of $\partial$ simply indicate that there is a significant downward trend in these countries' relative health expenditures. Figure 8, for example, shows the deviation in Canada's national health expenditures from the regression line that would be predicted based on the other non-U.S. countries in the sample. The estimates in the top panel show results when expenditures and GDP per capita are measured using the OECD's (2012) PPPs; the estimates in the bottom panel show estimates when the Penn World Table (2011) PPPs are used. Each panel contains three sets of estimates, corresponding to three of the country samples described above. Both sets of PPPs and all three country samples show the same downward trend in Canada's expenditures relative to the health spending that is predicted on the basis of the other countries' spending patterns. Note, however, that the downward trend in Canadian spending was substantially complete by 1980. If the trend in Canadian spending were judged by the path of relative expenditures after 1980, Canada would not appear to have any decline at all. Note also that even at the end of the analysis period, Canada's spending was still about 10 percent to 15 percent above the level that would be predicted based on the income - health spending relationship observed in the other non-U.S. countries. Canada's relative health spending has fallen since 1960, but it fell from a high initial level.

There is in fact a strong negative relationship between the amount of the countries' excess spending in the 1960s and early 1970s and our estimates of $\partial_{i}$. Although we have identified OECD countries with health expenditure growth that is slower than would be predicted in view of the growth in their real income, the downward trend in their relative spending may simply reflect reversion to the mean. Initially, high-spending countries tend to fall toward the mean spending of other countries, while initially low spending countries tend to experience growth spurts that bring their spending closer to the OECD average. If this is the typical longterm pattern of health spending change, the United States is a notable outlier. It began the 
observation period with average or somewhat above-average spending, given its income, but it generally increased the size of the gap over subsequent decades.

There is some ground for weak optimism about future U.S. health spending trends. Figure 9 shows the five-year moving average of growth in per capita health expenditures (2005 prices) for the United States and other high-income OECD countries. Other countries saw a noticeable slowdown of the rate of expenditure growth in the early 1980s, and the rate of annual increase has remained in the range of 2.5 percent to 3.5 percent per year in later periods. In contrast, U.S. spending grew rapidly up to 1995, moderated in the second half of the 1990s, but then showed another surge in the early 2000s. Growth slowed again in the most recent half decade. It is conceivable that the cost control measures in the recently passed Affordable Care Act will continue to restrain spending growth in the future.

\section{Why is U.S. Health Care Spending So High?}

As noted in the introduction, U.S. health care expenditures, as a share of income or on a per capita basis, far exceed spending in any other country. The issue of why the United States is so different has been the subject of considerable research, so far without a clear resolution. In the early 2000s, the OECD health care data were used as a framework to argue that that the differences between the United States and other OECD countries were largely a reflection of higher prices in the United States (Anderson and others, 2003) since researchers could find little evidence that Americans consumed a larger volume of health services. However, Cutler (2003) and others have argued that such studies fail to reflect the intensity of patients' interactions with the health care system and that the United States differs from other countries in the use of more intensive technologies for some diseases.

One view is that technological innovation is the driving force behind health cost increases. This interpretation finds support in some empirical work (Smith, Newhouse, and Freeland 2009). Estimates of the growth in per capita health expenditures that account for increases in average income, insurance coverage, and the aging of the population leave a large unexplained residual, and this is often identified as "technological change." Technological improvements in the delivery of health care may also explain steady reductions in mortality and morbidity. However, it is hard for us to accept technological change as a plausible and full explanation for cross-national differences in the rate expenditure growth. New health care 
technologies are widely adopted in most high-income countries, and the lags in adoption are not long. If the ultimate test of new technology is that it delivers better health outcomes - lower rates of mortality and morbidity - then it is hard to see evidence in cross-national health statistics that the United States has derived out-sized gains from faster adoption of better and more expensive technology.

The OECD currently publishes some information disaggregating health care expenditures by broad functions and across different kinds of providers. Those data are summarized in Table 2. They indicate that the United States spends more in nearly every category, but the largest differences are in ambulatory healthcare. While the United States spends moderately more on pharmaceuticals, and its administrative costs are clearly well above average, the large difference is in the provision of individual health services. Moreover, the classification of individual health care by institution is not particularly useful since the United States provides a large portion of its medical care on an outpatient basis, a large share of which occurs outside of hospitals. Thus, the category of ambulatory care is a heterogeneous grouping that is not necessarily the same across all of the countries. It has been suggested that the data would be more useful if they were organized by standardized categories of disease or treatment.

However, the most significant barrier to cross-national comparisons is the lack of meaningful measures of the prices of health services. Reliable price measures would help us to answer the basic question of whether the greater amount of spending in the United States is largely a reflection of higher prices or the provision of more health services. Most available measures of medical prices rely on estimates of the prices of the inputs rather than the outcomes. The use of a weighted sum of the input prices to define the output price eliminates any role for improvement in the productivity of the health care industry. ${ }^{2}$ Thus, researchers have pushed for the development of price measures that focus on measures of medical care outcomes (Cutler and Berndt 2001).

The difficulties in measuring price changes in health care are common in many service industries and center on the definition of output, the appropriate choice of the unit of measurement, and the monitoring of quality changes. In addition, the methods appropriate to

\footnotetext{
${ }^{2}$ The basic cost components used in the national account comparisons are: compensation of employees, intermediate consumption, gross operating surplus, net taxes on production, and receipts from sales OECD (2007). We have not used those health-specific PPPs, preferring to adjust only at the level of the PPPs for total GDP.
} 
partitioning the change in nominal expenditures between two time periods within a country into its price and volume components are fundamentally the same as those that arise in the partitioning of cross-border differences in expenditures. Some progress has been made.

Researchers have developed standardized classifications that group medical interventions into relatively homogeneous disease categories. By following the cost of treatment within a narrowly defined Diagnostic-Related Group (DRG) category, it is possible to develop price indexes for medical services that are comparable to the matched-model price indexes used in other sectors of the economy. Disease-based price indexes have been constructed for tracking changes in prices for the treatment of heart attacks, stroke, breast cancer, arthritis, premature births and cataract surgery. While the methodology is still limited to a subset of medical care, it is being expanded as a tool for dividing the growth in health care spending between price and volume changes.

International comparisons are largely based on purchasing power parities (PPP), which, as discussed above, are ratios of the prices in national currencies of the same good or service in different countries. Thus, the price comparison is the same as for a price index except that the spatial linkages are made across countries rather than time. The focus is on ensuring that the medical treatments whose prices are being compared are sufficiently similar across countries.

An alternative approach would involve the measurement of the number of procedures, rather than the price. Since total expenditure is the product of quantity times price, the two approaches should yield equivalent conclusions. In some cases, it is difficult to consolidate the payments from a variety of different payers and assign them to specific procedures. However, the aggregation of quantity-based measures requires the construction of price weights, just as the aggregation of a set of price indexes requires quantity weights. Thus, the two approaches are not so different in their basic data requirements.

Hospital Service Prices. Research at the OECD has emphasized the PPP methodology to construct its international comparisons of health care costs. OECD researchers have used an extension of the DRG classification system to develop comparable categories of health treatments. Because the prices for those services are often negotiated or administered as opposed to being established in a market, they work with the member countries to develop quasi-price measures that reflect common systems of cost assignment. In a 2010 report (Koechlin, Lorenzoni, and Shreyer 2010), OECD analysts described a comparison for inpatient hospital 
services in 2007 for 12 OECD countries that included the United States. They incorporated nine specific cases of medical services and 23 surgical procedures that they believed represented comparable medical treatments. Examples of the degree of specificity were a normal delivery, caesarean section, knee replacement, and hip replacement. Because the service categories were very narrowly defined by case type, the researchers argued that quality differences were excluded in a fashion similar to the matched-model price comparison for non-medical products.

The results of the OECD study are reported in Table 3. The price comparisons are expressed as indexes with the average of the 12 countries set equal to 100 . Thus, total inpatient services in the United States were 164 percent of the group average and were 45 (164/113) percent above the level of Canada. While the United States was not the highest-cost reporter in all of the individual procedures, it was never lower than fourth, and it was first in two-thirds of the specific comparisons. ${ }^{3}$ The results are particularly striking for the United States when we take account of the fact that for GDP as a whole, the U.S. price level is 10 percent below the average for the compared countries. Thus, the relative inpatient heath service costs in the United States are even higher than indicated by the PPPs.

On the other hand, health care is a highly labor-intensive industry, and we should expect high-income countries to have high wages and hence higher prices for health services. ${ }^{4}$ Thus, some of the premium of U.S. health care prices over those of countries such as Portugal, Slovenia, and Korea are accounted for by differences in relative incomes. Within this small sample, a regression-based adjustment for income eliminates a large portion of the difference in price levels and leaves U.S. service prices about 10 percent to 15 percent higher than the norm. Because of the inclusion of the lower-income countries within a relatively small sample, it may be better to focus on a comparison of the United States solely with other high-income countries, but the differences would still be substantial.

\footnotetext{
${ }^{3}$ The reported prices for individual procedures are similar to the comparative price reports for 20092011 published by International Federation of Health Plans (2012); but the United States is less of an outlier in the OECD study.

${ }^{4}$ The price of health services could vary across countries because of differences in input prices, productivity, or the quality of the services. The study attempted to control for quality differences by focusing on relatively narrowly-defined procedures, and the output prices were meant to reflect differences in both input prices and productivity.
} 
Pharmaceutical Prices. Pharmaceuticals would appear to represent a relatively standardized product sold in many countries, and thus the comparison of prices in various countries appears to be quite straightforward. In practice, however, studies have reached varying conclusions about cross-border drug prices. The issue is complicated by the different structures of the national systems for drug distribution. In the United States, for example, only a minority of consumers pay directly for their prescriptions. A growing share of retail sales pass through health insurers who negotiate confidential discounts. Generic prices are much lower than the list prices of branded products, but countries appear to vary substantially in the extent to which they rely on generic drugs. Variations in value-added (VAT) tax rates create another source of price differences. The fact that all of these determinants change rapidly implies that it is difficult to construct price indexes that are representative over time and across countries.

A recent study by Kanavos and Vandoros (2011) that addressed many of these issues used data on the top-selling 50 prescription drugs in 15 OECD countries in 2007. The price measures were inclusive of all discounts or rebates. The authors used statistical regression analysis to control for differences in VAT rates, the age of the drug, and the existence of a generic, and they concluded that U.S. prices were about 30 percent higher on average. The gap is sizable but smaller than the percentage difference found in other studies. It also appears that U.S. consumers pay higher prices for branded drugs, but U.S. prices of generic drugs are often lower than prices for the same drugs in other countries.

Physician Fees. The disaggregated OECD statistics in Table 2 indicate that the largest difference in per capita health expenditures between the United States and other OECD countries is in ambulatory care. The differences are even more striking when the comparison is limited to care provided in physicians' offices. In 2010 , those expenditures were $\$ 1,675$ per capita in the United States compared with an average of $\$ 400$ in the other 20 high-income countries. However, we do not know whether that difference is a reflection of the provision of more services or of higher incomes received by physicians.

A recent paper by Laugesen and Glied (2011) indentified some of the sources of the cost differences for primary care physicians and orthopedic surgeons in six OECD countries (Australia, Canada, France, Germany, United Kingdom, and the United States). While private insurance payment rates are proprietary and generally unavailable, Laugesen and Glied obtained 
aggregated data covering the average fee for an office visit and a hip replacement by Medicare and private payers. They also developed volume measures based on the number of primary care office visits and the number of hip replacements. On a per capita basis, the United States had by far the lowest number of office visits, but the average fee per visit was the highest of the six countries, although fees in the United Kingdom and Canada were near the same level. For hip replacements, the United States performed fewer surgeries on a per capita basis than France, Germany and the United Kingdom, but the fees were nearly twice as high.

The combination of volume and fees provided Laugesen and Glied (2011) with their estimates of gross physician income, and from this total they deducted office expenses to obtain an estimate of physician earnings. Indexing the level of primary care earnings at 100 for the United States, primary care earnings ranged from a low of 50 percent in Australia to 86 percent in the United Kingdom. Orthopedic surgeons' income ranged from 35 percent of the U.S. level in France to 73 percent in the United Kingdom. It is also noteworthy that the earnings of orthopedic surgeons in the United States were more than twice those of primary care physicians. Laugesen and Glied's (2011) major conclusion is that the higher level of physician expenditures in the United States is largely a reflection of higher prices rather than a greater volume of services. The authors also show that differences in the private cost of a medical education account for some of the income differences. U.S. physicians pay for a larger portion of their own education. However, the differences between the annual incomes of orthopedic surgeons in the United States and the comparison countries are far greater than the differences in the annualized private costs of the doctors' education.

Overview. The above studies are still quite limited in their coverage of the full range of health care services. They have not attempted to examine some of the more complex treatments that might involve significant cross-countries differences in the quality or intensity of the health services. However, they consistently demonstrate that large differences in health care expenditures between the United States and other high-income countries are due to differences in the prices that Americans pay for their health services. It is compatible with the comparisons of health outcomes that find small or no consistent pattern of difference across countries. The international comparisons do not yet have a time dimension, so we do not know if the size of the 
U.S. price differential has grown over time, and thereby accounts for the faster rate of growth of U.S. spending in past years.

\section{Conclusion}

Our comparison of U.S. heath care spending with that of other high-income OECD countries clearly demonstrates the extent to which the United States is an outlier in health expenditures. It spends far more of its income on health care than do other rich countries. Even after making adjustments for differences in income per capita, the United States spends about 70 percent more than the other countries in our sample. We also find that much of this gap developed between 1980 and the mid-1990s when the growth in per capita U.S. health expenditures far out-stripped comparable rates of spending growth in other wealthy countries. There was a second milder episode of outsized growth in the early 2000s, but U.S. expenditure growth has moderated in recent years to match the growth rate of other countries.

We also identified six countries, including most of Scandinavia, that have been able to moderate their health expenditure growth, at least compared to other countries with similar average incomes. However, we note that these were also countries that had higher-than-expected health spending, given their average incomes, in the 1960s and 1970s. Thus, the slowdown in their health expenditure growth may simply reflect a reversion of their spending toward the OECD mean. Their experiences may offer few if any lessons for the United States.

Conspicuously, there is no evidence of sustained reversion to the mean on the part of the United States.

Finally, we examined a range of recent studies that attempted to divide the excess health spending in the United States between the part attributable to a higher volume of health care services and the part attributable to higher health care prices. Our interpretation of these studies is that they show that much of the current excess in U.S. health costs is traceable to higher prices for health care goods and services. The failure of the United States to obtain better-than-average health outcomes in exchange for its much-higher-than-average health outlays tends to reinforce this view. Compared with other OECD countries, the United States has been slow to develop institutions or global budget constraints that notably restrain the pace of health cost growth. 


\section{References}

Anderson, Gerald F., Uwe E. Reinhardt, Peter S. Hussey, and Verduhi Petrosyan. 2003. "It's the Prices, Stupid: Why the United States Is So Different from Other Countries," Health Affairs, May/June 2003, vol. 22(3): 89-105.

Cutler, David M., and Ernest R.Berndt, (eds.). 2001. Medical Care Output and Productivity, National Bureau of Economic Research Studies in Income and Wealth, Vol. 62, Chicago: The University of Chicago Press.

Cutler, David M. 2003. “A Framework for Evaluating Medical Care Systems.” In A DiseaseBased Comparison of Health Systems: What Is Best and at What Cost? Paris: OECD.

Heston, Alan, Robert Summers, and Bettina Aten. 2011. Penn World Table Version 7.0, Philadelphia: Center for International Comparisons of Production, Income and Prices at the University of Pennsylvania (May 2011).

Kanavos, Panos, and Sotiris Vandoros. 2011. "Drugs US: Are Prices Too High? Measuring International Pharmaceutical Price Differences," Significance, the Royal Statistical Society, vol. 8: 15-18.

Koechlin, Franchette, Luca Lorenzoni and Paul Schreyer (2010), "Comparing Price Levels of Hospital Services Across Countries: Results of Pilot Study”, OECD Health Working Papers, No. 53. Paris: OECD.

Laugesen, Miriam J. and Sherry A. Glied. 2010. "Higher Fees Paid to US Physicians Drive Higher Spending for Physician Services Compared to Other Countries," Health Affairs, vol. 30, No 9: 1647-56.

OECD. 2007. Purchasing Power Parities and Real Expenditures, 2005 Benchmark Year, Paris: OECD.

Smith, Sheila, Joseph P. Newhouse, and Mark S. Freeland. 2009. "Income, Insurance, And Technology: Why Does Health Spending Outpace Economic Growth?” Health Affairs, 28, no.5:1276-1284

U.S. Bureau of Labor Statistics, Division of International Labor Comparisons. 2011. International Comparisons of GDP per Capita and per Hour through 2010. Washington, DC: U.S. Bureau of Labor Statistics. 
Table 1. Estimated Declines in Countries' Relative National Health Expenditures, 1960s through 2010

\begin{tabular}{|c|c|c|c|c|c|c|c|c|c|c|c|}
\hline \multicolumn{4}{|c|}{$\begin{array}{c}\text { Penn-World (2011) PPPs } \\
\text { (2005 \$) }\end{array}$} & \multicolumn{3}{|c|}{$\begin{array}{c}\text { OECD (2012) PPPs } \\
\text { (2005\$) }\end{array}$} & & \multicolumn{4}{|c|}{ BLS (2011) PPPs (2010\$) } \\
\hline $\begin{array}{l}\text { Countr } \\
\mathrm{y} \\
\end{array}$ & $\begin{array}{c}\text { Error } \\
\text { trend } \\
\text { (log } \\
\text { points } \\
\quad) \\
\end{array}$ & $\begin{array}{r}\mathrm{p}- \\
\text { value }\end{array}$ & & $\begin{array}{l}\text { Countr } \\
\mathrm{y} \\
\end{array}$ & $\begin{array}{c}\text { Error } \\
\text { trend } \\
(\log \\
\text { points } \\
\quad) \\
\end{array}$ & $\begin{array}{r}\mathrm{p}- \\
\text { value } \\
\end{array}$ & & $\begin{array}{l}\text { Countr } \\
\mathrm{y}\end{array}$ & $\begin{array}{c}\text { Error } \\
\text { trend } \\
\text { (log } \\
\text { points } \\
\quad) \\
\end{array}$ & $\begin{array}{r}\mathrm{p}- \\
\text { value }\end{array}$ & \\
\hline \multicolumn{12}{|c|}{ All-country sample } \\
\hline IDE & 0.014 & 0 & $*$ & CUVF & 0.010 & 000 & * & IDF & 0.022 & 0 & * \\
\hline & 0.009 & & & & 0.009 & & & & 0.008 & & \\
\hline DEN & 7 & 0.00 & * & JAP & 5 & 0.00 & * & SWE & 2 & 0.00 & * \\
\hline & $0.008^{-}$ & & & & $0.009^{-}$ & & & & 0.007 & & \\
\hline SWE & & 0.00 & $*$ & DEN & 3 & 0.00 & $*$ & DEN & 7 & 0.00 & * \\
\hline & 0.007 & & & & 0.008 & & & & 0.004 & & \\
\hline FIN & 0 & 0.00 & $*$ & FIN & 6 & 0.00 & $*$ & CAN & 4 & 0.01 & $*$ \\
\hline & $0.005^{-}$ & & & & $0.005^{-}$ & & & & $0.004^{-}$ & & \\
\hline JAP & 7 & 0.00 & * & CAN & 0 & 0.00 & * & FIN & 0 & 0.13 & \\
\hline & 0.005 & & & & 0.002 & & & & 0.004 & & \\
\hline CAN & 2 & 0.00 & * & IRE & 5 & 0.66 & & JAP & 0 & 0.05 & * \\
\hline & $0.002^{-}$ & & & & $0.002^{-}$ & & & & 0.003 & & \\
\hline $\mathrm{NZ}$ & 0 & 0.36 & & UK & 1 & 0.15 & & ITA & 9 & 0.47 & \\
\hline & 0.001 & & & & 0.000 & & & & $0.000^{-}$ & & \\
\hline UK & 7 & 0.27 & & NET & 3 & 0.90 & & GER & 8 & 0.60 & \\
\hline & 0.000 & & & & 0.000 & & & & 0.000 & & \\
\hline NTH & $\begin{array}{r}6 \\
0.000\end{array}$ & 0.80 & & AUT & $\begin{array}{r}1 \\
0.001\end{array}$ & 0.95 & & UK & $\begin{array}{r}5 \\
0.000\end{array}$ & 0.75 & \\
\hline AUT & 6 & 0.69 & & AUS & 0 & 0.58 & & NTH & 6 & 0.81 & \\
\hline & 0.000 & & & & 0.002 & & & & 0.001 & & \\
\hline AUS & $\begin{array}{r}8 \\
0.002\end{array}$ & 0.66 & & FRA & $\begin{array}{r}0 \\
0.005\end{array}$ & 0.38 & & AUT & $\begin{array}{r}8 \\
0.002\end{array}$ & 0.26 & \\
\hline FRA & 8 & 0.24 & & BEL & 2 & 0.01 & * & AUS & 1 & 0.28 & \\
\hline & 0.005 & & & & 0.006 & & & & 0.004 & & \\
\hline NOR & 7 & 0.00 & * & NOR & 5 & 0.00 & * & FRA & 2 & 0.08 & \\
\hline
\end{tabular}




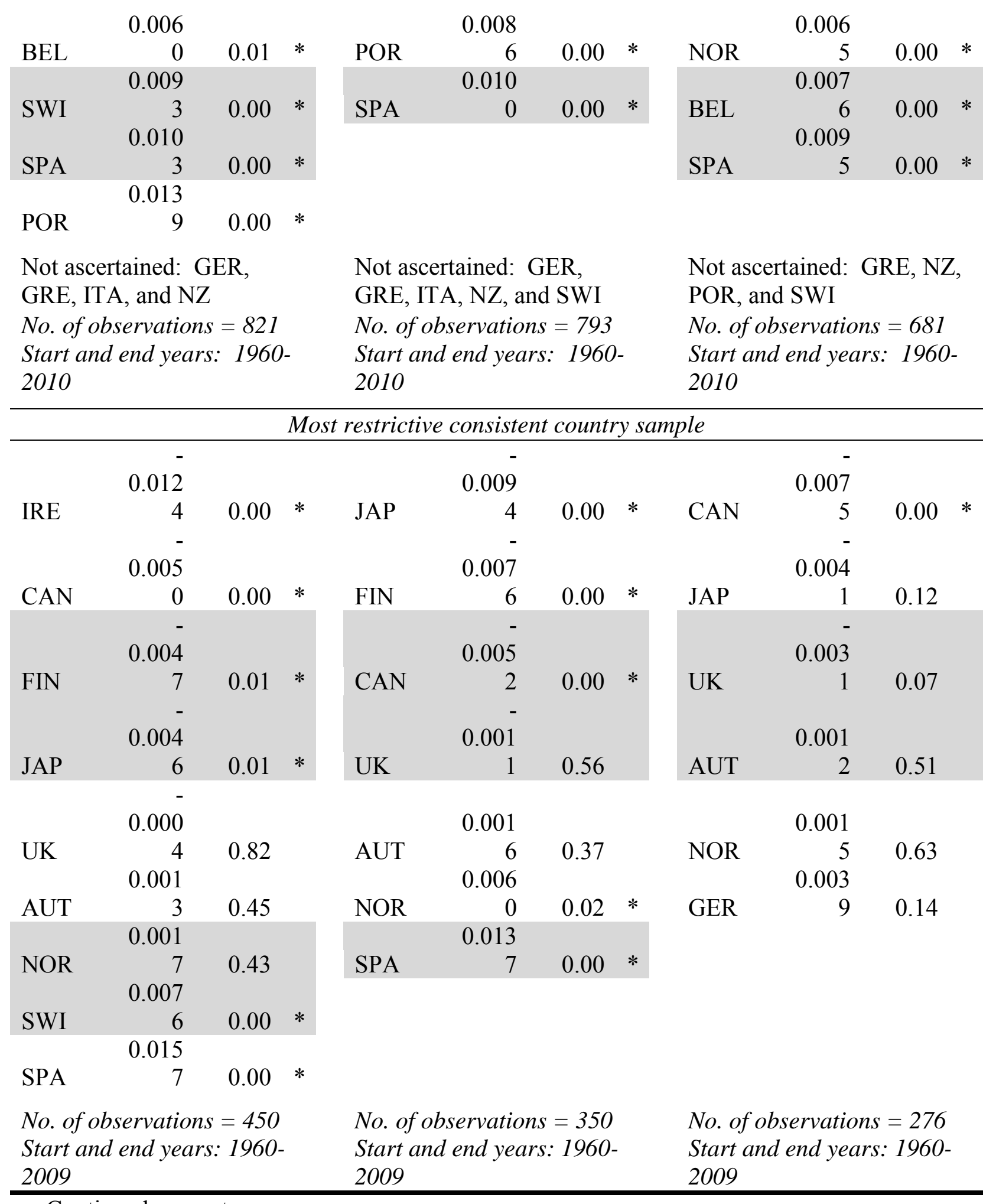

Continued on next page. 
Table 1. Estimated Declines (continued)

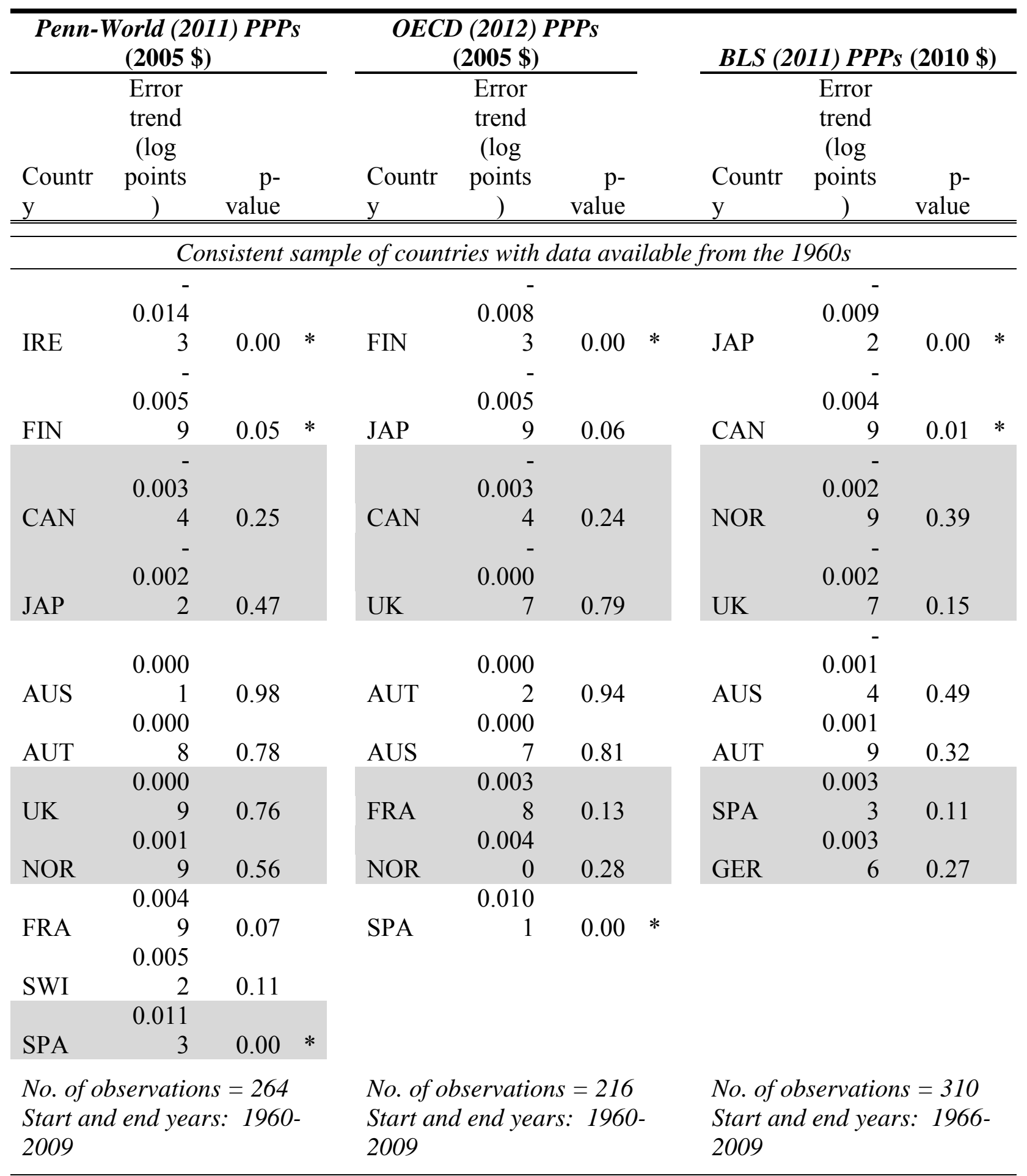

Least restrictive consistent country sample

\begin{tabular}{|c|c|c|c|c|c|c|c|c|c|c|c|}
\hline & - & & & & - & & & & - & & \\
\hline & & & & & & & & & 0.024 & & \\
\hline IRE & 7 & 0.00 & $*$ & FIN & 9 & 0.01 & $*$ & IRE & 2 & 0.00 & $*$ \\
\hline FIN & - & 0.02 & $*$ & SWE & - & 0.01 & $*$ & SWE & - & 0.00 & $*$ \\
\hline
\end{tabular}




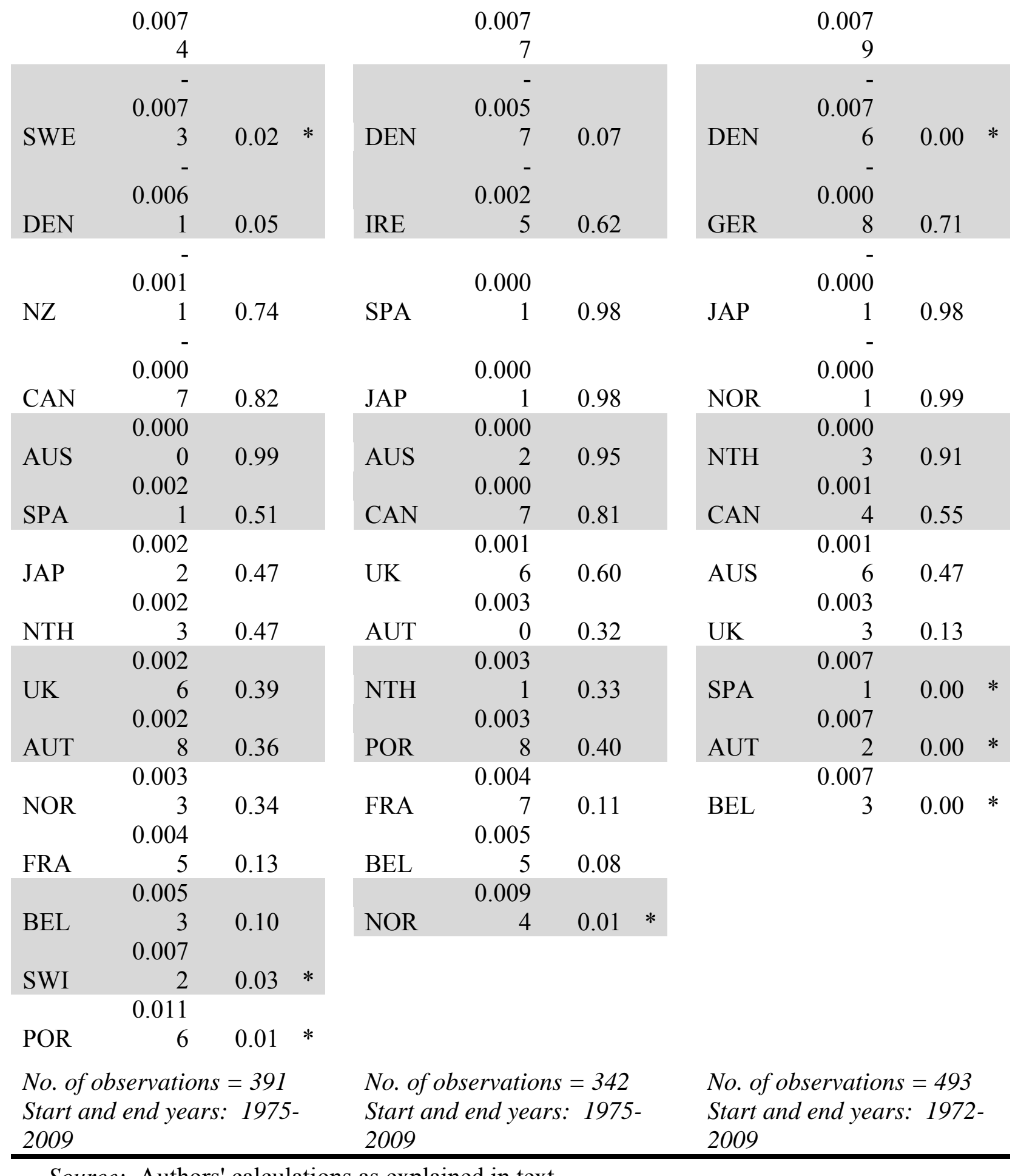

Source: Authors' calculations as explained in text. 
Table 2. Health Expenditures by Function and Provider, 2010

Percent of GDP

\begin{tabular}{|c|c|c|c|c|c|c|c|c|}
\hline \multirow[b]{2}{*}{ Country } & \multicolumn{4}{|c|}{ Individual Health Care Expenditures } & \multirow[b]{2}{*}{$\begin{array}{c}\text { Pharmaceutica } \\
\text { Is and medical } \\
\text { devices }\end{array}$} & \multirow[b]{2}{*}{$\begin{array}{c}\text { Administratio } \\
\mathbf{n}\end{array}$} & \multirow[b]{2}{*}{$\begin{array}{c}\text { Capital } \\
\text { formatio } \\
\mathbf{n} \\
\end{array}$} & \multirow[b]{2}{*}{$\begin{array}{c}\text { Total } \\
\text { expenditure } \\
\text { s } \\
\end{array}$} \\
\hline & $\begin{array}{c}\text { Hospital } \\
\mathrm{S} \\
\end{array}$ & $\begin{array}{l}\text { Nursing } \\
\text { and } \\
\text { residentia } \\
1 \text { care } \\
\text { facilities } \\
\end{array}$ & $\begin{array}{c}\text { Ambulator } \\
\text { y care } \\
\text { facilities } \\
\end{array}$ & Total & & & & \\
\hline Australia & 3.54 & 0.00 & 3.07 & 6.65 & 1.34 & 0.28 & 0.39 & 9.10 \\
\hline Austria & 4.03 & 0.92 & 2.39 & 8.08 & 1.31 & 0.38 & 0.58 & 10.98 \\
\hline Belgium & 3.22 & 1.29 & 3.17 & 7.93 & 1.66 & 0.57 & 0.00 & 10.54 \\
\hline Canada & 3.22 & 1.14 & 3.04 & 7.40 & 1.90 & 0.37 & 0.61 & 11.38 \\
\hline Denmark & 4.82 & 1.43 & 2.81 & 9.10 & 0.82 & 0.13 & 0.41 & 11.12 \\
\hline Finland & 2.94 & 0.63 & 2.60 & 6.37 & 1.24 & 0.16 & 0.43 & 8.91 \\
\hline France & 3.99 & 0.66 & 3.10 & 7.81 & 1.86 & 0.82 & 0.41 & 11.67 \\
\hline Germany & 3.31 & 0.88 & 3.23 & 7.94 & 1.71 & 0.62 & 0.41 & 11.60 \\
\hline Japan & 4.10 & 0.35 & 2.04 & 6.80 & 1.95 & 0.16 & 0.17 & 9.38 \\
\hline Netherlands & 3.87 & 2.57 & 1.90 & 8.52 & 1.14 & 0.44 & 0.78 & 11.99 \\
\hline New Zealand & 3.88 & 0.97 & 3.02 & 7.94 & 0.96 & 0.40 & 0.00 & 10.19 \\
\hline Norway & 3.56 & 1.75 & 2.49 & 7.95 & 0.69 & 0.08 & 0.35 & 9.41 \\
\hline Portugal & 3.86 & 0.15 & 3.19 & 7.37 & 2.00 & 0.17 & 0.57 & 10.73 \\
\hline Spain & 3.81 & 0.52 & 2.32 & 6.74 & 1.80 & 0.29 & 0.27 & 9.57 \\
\hline Sweden & 4.14 & n.a. & 1.84 & 7.07 & 1.21 & 0.13 & 0.50 & 9.55 \\
\hline Switzerland & 4.08 & 1.96 & 3.18 & 9.22 & 1.10 & 0.54 & 0.00 & 11.36 \\
\hline United States & 5.63 & 0.99 & 6.10 & 12.73 & 2.10 & 1.22 & 0.69 & 17.61 \\
\hline OECD & 4.62 & 0.85 & 4.27 & 9.93 & 1.89 & 0.79 & 0.55 & 14.59 \\
\hline OECD less US & 3.70 & 0.72 & 2.63 & 7.42 & 1.71 & 0.40 & 0.42 & 11.87 \\
\hline
\end{tabular}

Source: OECD heath data, 2012

NOTE: The table excludes Italy, UK, Ireland \& Greece for lack of data. Australia, Japan and Spain use 2009 data. Some components are not shown separately. The data are aggregated across countries using 2005 purchasing power parities. 
Table 3. Comparative Price Levels for Hospital Services and GDP, 2007*

\begin{tabular}{lcccc}
\hline & $\begin{array}{c}\text { Total } \\
\text { Inpatient } \\
\text { medical } \\
\text { services }\end{array}$ & $\begin{array}{c}\text { Inpatient } \\
\text { surgical } \\
\text { services }\end{array}$ & $\begin{array}{c}\text { inpatient } \\
\text { hospital } \\
\text { services }\end{array}$ & $\begin{array}{c}\text { Price of } \\
\text { GDP }\end{array}$ \\
\hline \hline Australia & 122 & 124 & 123 & 104 \\
Canada & $\mathbf{1 2 5}$ & $\mathbf{1 1 3}$ & $\mathbf{1 1 3}$ & $\mathbf{1 0 1}$ \\
Finland & 91 & 99 & 98 & 118 \\
France & $\mathbf{1 4 0}$ & $\mathbf{1 1 4}$ & $\mathbf{1 2 1}$ & $\mathbf{1 1 2}$ \\
Italy & 158 & 132 & 140 & 103 \\
Israel & $\mathbf{6 0}$ & $\mathbf{6 5}$ & $\mathbf{6 2}$ & $\mathbf{1 2 0}$ \\
Korea & 37 & 66 & 57 & 73 \\
Portugal & $\mathbf{9 0}$ & $\mathbf{8 1}$ & $\mathbf{8 5}$ & $\mathbf{8 3}$ \\
Slovenia & 65 & 56 & 59 & 79 \\
Sweden & $\mathbf{1 1 2}$ & $\mathbf{1 1 6}$ & $\mathbf{1 1 4}$ & $\mathbf{1 2 1}$ \\
United States & 173 & 163 & 164 & 90 \\
\hline All-country & & & & \\
average & $\mathbf{1 0 0}$ & $\mathbf{1 0 0}$ & $\mathbf{1 0 0}$ & $\mathbf{1 0 0}$ \\
\hline
\end{tabular}

Source: Koechlin, Lorenzoni and P. Schreyer (2010), page 15. The Nether-lands is not shown separately. 
Appendix Table 1. Availability of National Data on Health Care Expenditures using Consistent Estimates of Purchasing Power Parity Exchange Rates, 1960-2010

\begin{tabular}{|c|c|c|c|c|c|c|c|c|c|}
\hline \multirow[b]{2}{*}{ Country } & \multicolumn{3}{|c|}{ OECD PPPs $(2005 \$)$} & \multicolumn{3}{|c|}{$\begin{array}{c}\text { Penn-World (2011) PPPs } \\
(2005 \$)\end{array}$} & \multicolumn{3}{|c|}{$\begin{array}{c}\text { BLS (2011) PPPs (2010 } \\
\$)\end{array}$} \\
\hline & $\begin{array}{c}\text { Yrs. } \\
\text { of } \\
\text { data }\end{array}$ & $\begin{array}{l}\text { First } \\
\text { year }\end{array}$ & $\begin{array}{l}\text { Last } \\
\text { year }\end{array}$ & $\begin{array}{c}\text { Yrs. of } \\
\text { data }\end{array}$ & $\begin{array}{l}\text { First } \\
\text { year }\end{array}$ & $\begin{array}{l}\text { Last } \\
\text { year }\end{array}$ & $\begin{array}{c}\text { Yrs. } \\
\text { of } \\
\text { data }\end{array}$ & $\begin{array}{l}\text { First } \\
\text { year }\end{array}$ & $\begin{array}{l}\text { Last } \\
\text { year }\end{array}$ \\
\hline Australia & 43 & 1960 & 2009 & 43 & 1960 & 2009 & 43 & 1960 & 2009 \\
\hline Austria & 51 & 1960 & 2010 & 51 & 1960 & 2010 & 51 & 1960 & 2010 \\
\hline Belgium & 41 & 1970 & 2010 & 41 & 1970 & 2010 & 41 & 1970 & 2010 \\
\hline Canada & 51 & 1960 & 2010 & 51 & 1960 & 2010 & 51 & 1960 & 2010 \\
\hline Denmark & 40 & 1971 & 2010 & 40 & 1971 & 2010 & 40 & 1971 & 2010 \\
\hline Finland & 51 & 1960 & 2010 & 51 & 1960 & 2010 & 36 & 1975 & 2010 \\
\hline France & 27 & 1960 & 2010 & 27 & 1960 & 2010 & 27 & 1960 & 2010 \\
\hline Germany & 19 & 1992 & 2010 & 19 & 1992 & 2010 & 50 & 1960 & 2010 \\
\hline Greece & 16 & 1995 & 2010 & 26 & 1970 & 2010 & 0 & N.A. & N.A. \\
\hline Ireland & 21 & 1990 & 2010 & 51 & 1960 & 2010 & 41 & 1970 & 2010 \\
\hline Italy & 23 & 1988 & 2010 & 23 & 1988 & 2010 & 23 & 1988 & 2010 \\
\hline Japan & 50 & 1960 & 2009 & 50 & 1960 & 2009 & 50 & 1960 & 2009 \\
\hline $\begin{array}{l}\text { Netherlands } \\
\text { New }\end{array}$ & 39 & 1972 & 2010 & 39 & 1972 & 2010 & 39 & 1972 & 2010 \\
\hline Zealand & 41 & 1970 & 2009 & 40 & 1970 & 2009 & 0 & N.A. & N.A. \\
\hline Norway & 51 & 1960 & 2010 & 51 & 1960 & 2010 & 51 & 1960 & 2010 \\
\hline Portugal & 41 & 1970 & 2010 & 41 & 1970 & 2010 & 0 & N.A. & N.A. \\
\hline Spain & 50 & 1960 & 2009 & 50 & 1960 & 2009 & 46 & 1964 & 2009 \\
\hline Sweden & 41 & 1970 & 2010 & 41 & 1970 & 2010 & 41 & 1970 & 2010 \\
\hline Switzerland & 46 & 1965 & 2010 & 51 & 1960 & 2010 & 0 & N.A. & N.A. \\
\hline UK & 51 & 1960 & 2010 & 51 & 1960 & 2010 & 51 & 1960 & 2010 \\
\hline USA & 51 & 1960 & 2010 & 51 & 1960 & 2010 & 51 & 1960 & 2010 \\
\hline
\end{tabular}

Note: A country supplies valid data for a given year if (a) the OECD has estimated its national health expenditures for the year; and (b) the indicated source of PPP exchange rates has published data on the country's GDP per capita in that year. 
Figure 1. OASDI Taxable Earnings as a Percent of U.S. GDP, 1980-2011

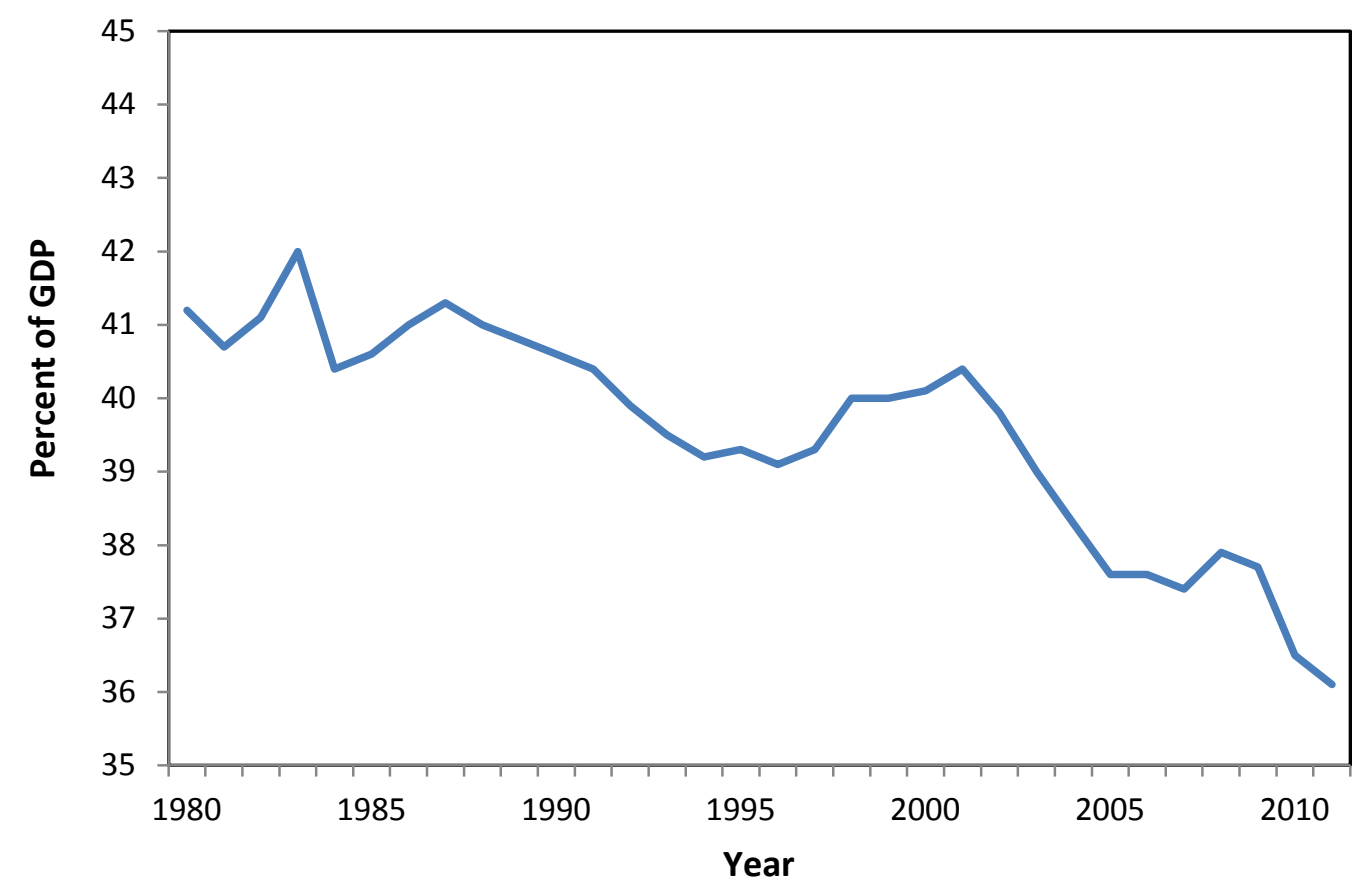

Source: OASDI, 2012 OASDI Trustees Report, supplemental single-year table VI.F5.

Figure 2. Employer Contributions for Employee Health Plans as a Percent of U.S. Labor Compensation, 1950-2010

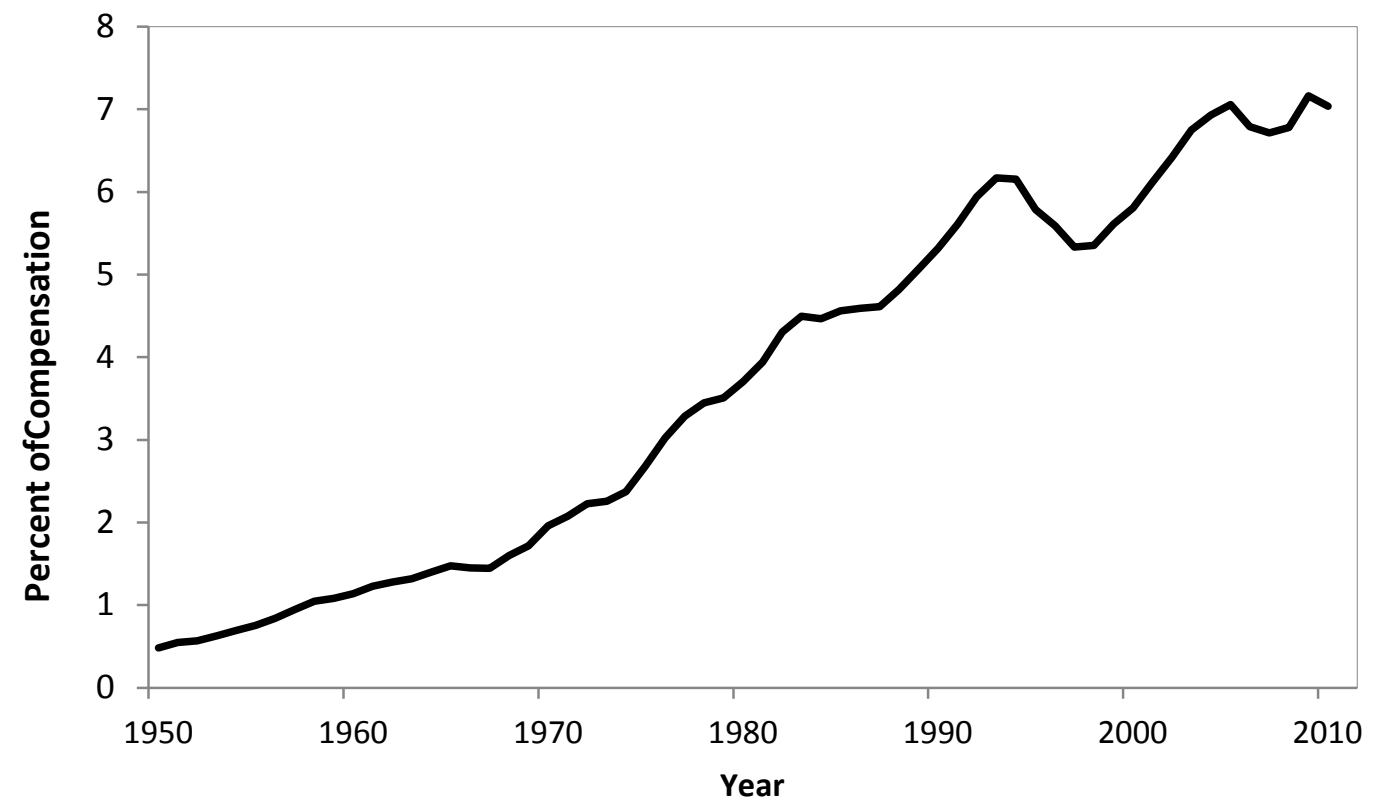

Source: Bureau of Economic Analysis, National Income and Product Accounts, tables 1.12 and 6.11 . 
Figure 3. Health Care Spending in High-Income OECD Countries, 1970-2010

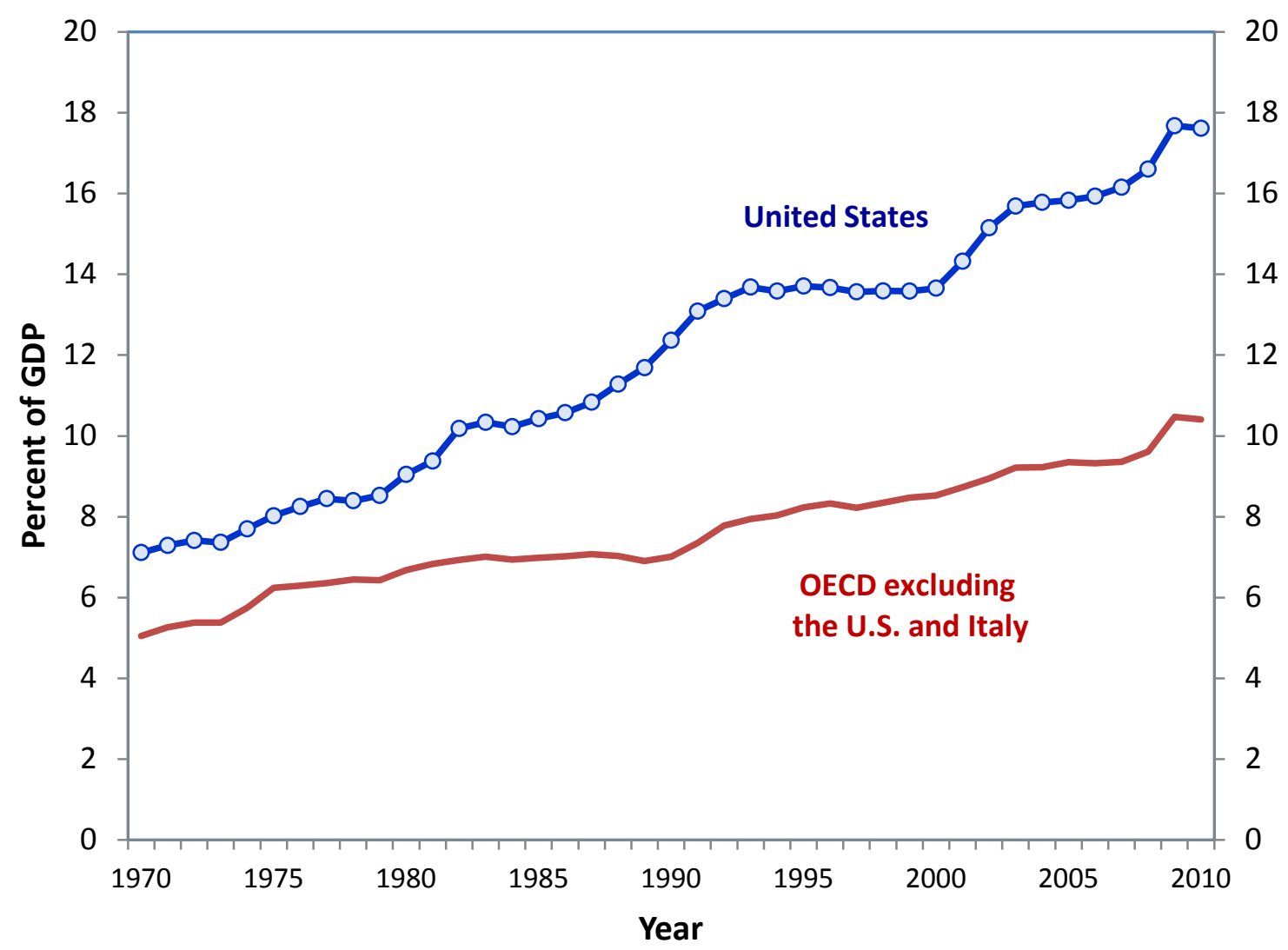

Source: OECD health data, 2012.

Note: The health expenditures and GDP of country groups were computed using OECD purchasing power exchange rates of 2005. The full list of 21 high-income countries is shown in the appendix table. Italy is excluded from the average shown above because its health spending data do not begin until 1988 . 
Figure 4a. Cross-National Estimates of Relation between National Health Expenditures Per Capita and Real GDP Per Capita, 1960 - 2009

Health care spending per capita and GDP per capita in 1960

Health spending (2005 \$)

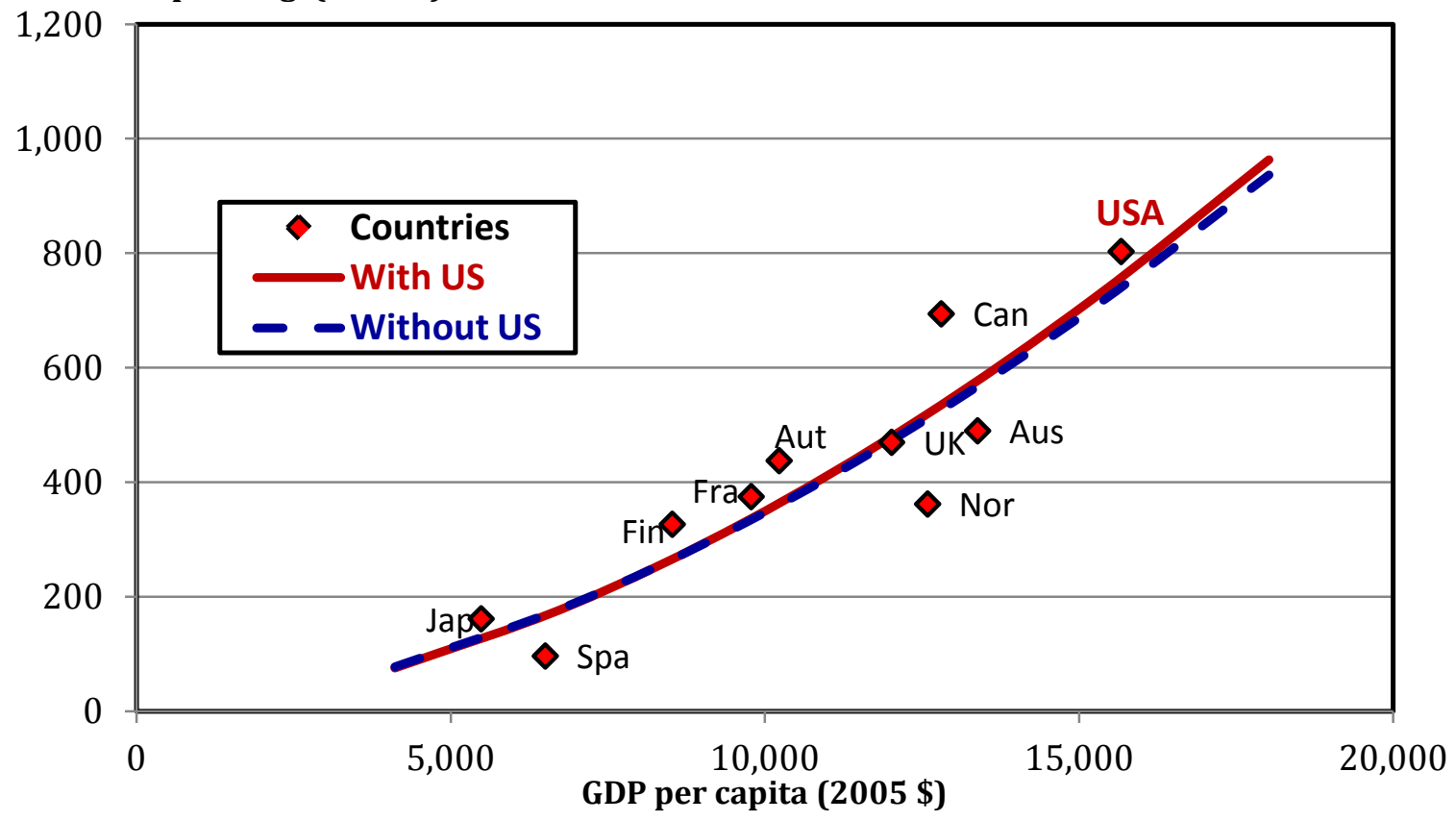

Health care spending per capita and GDP per capita in 1975

Health spending (2005 \$)

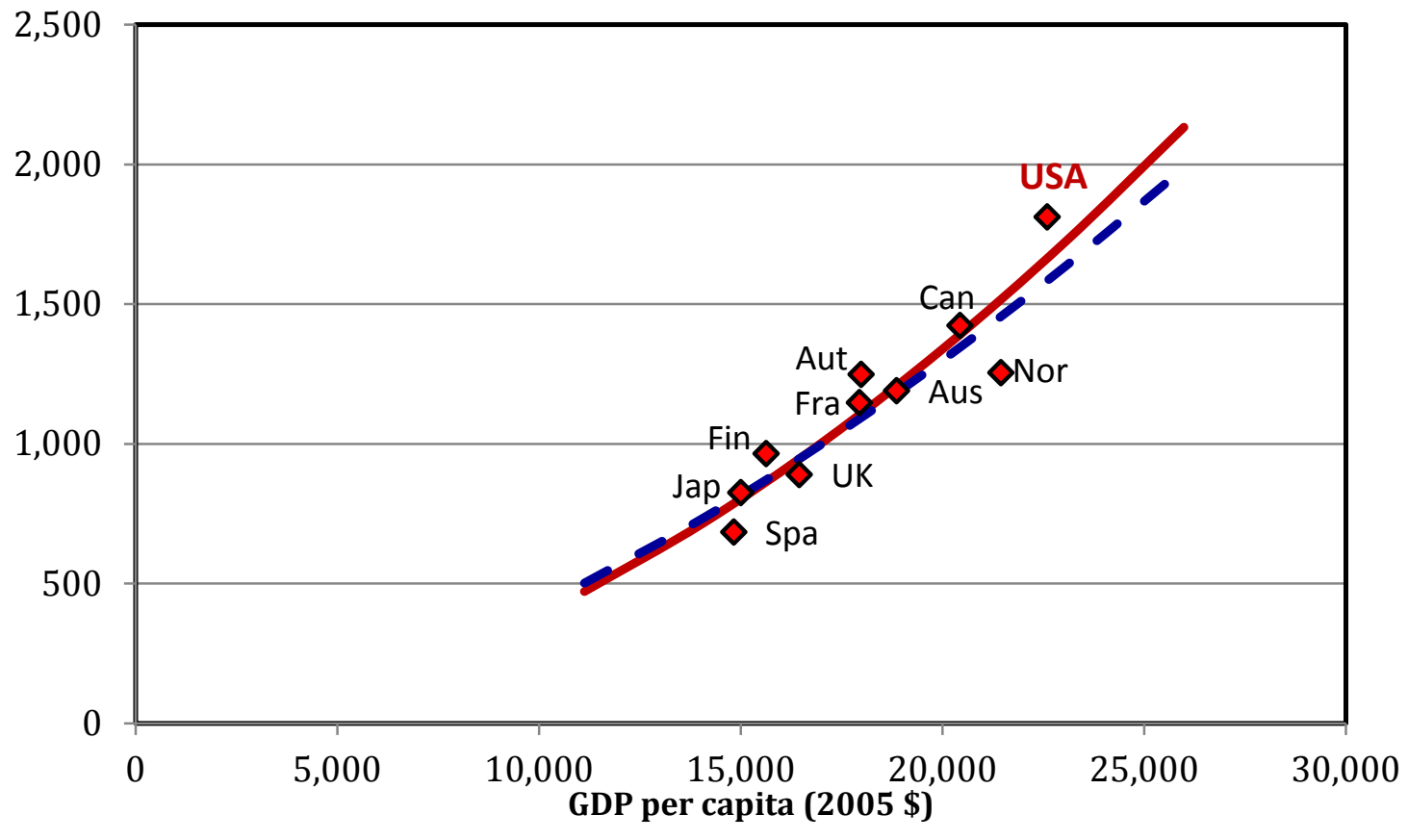

Source: Authors' calculations as explained in text. 
Figure 4b. Cross-National Estimates of Relation between National Health Expenditures Per Capita and Real GDP Per Capita, 1960 - 2009 (continued)

Health care spending per capita and GDP per capita in 1990

Health spending (2005 \$)

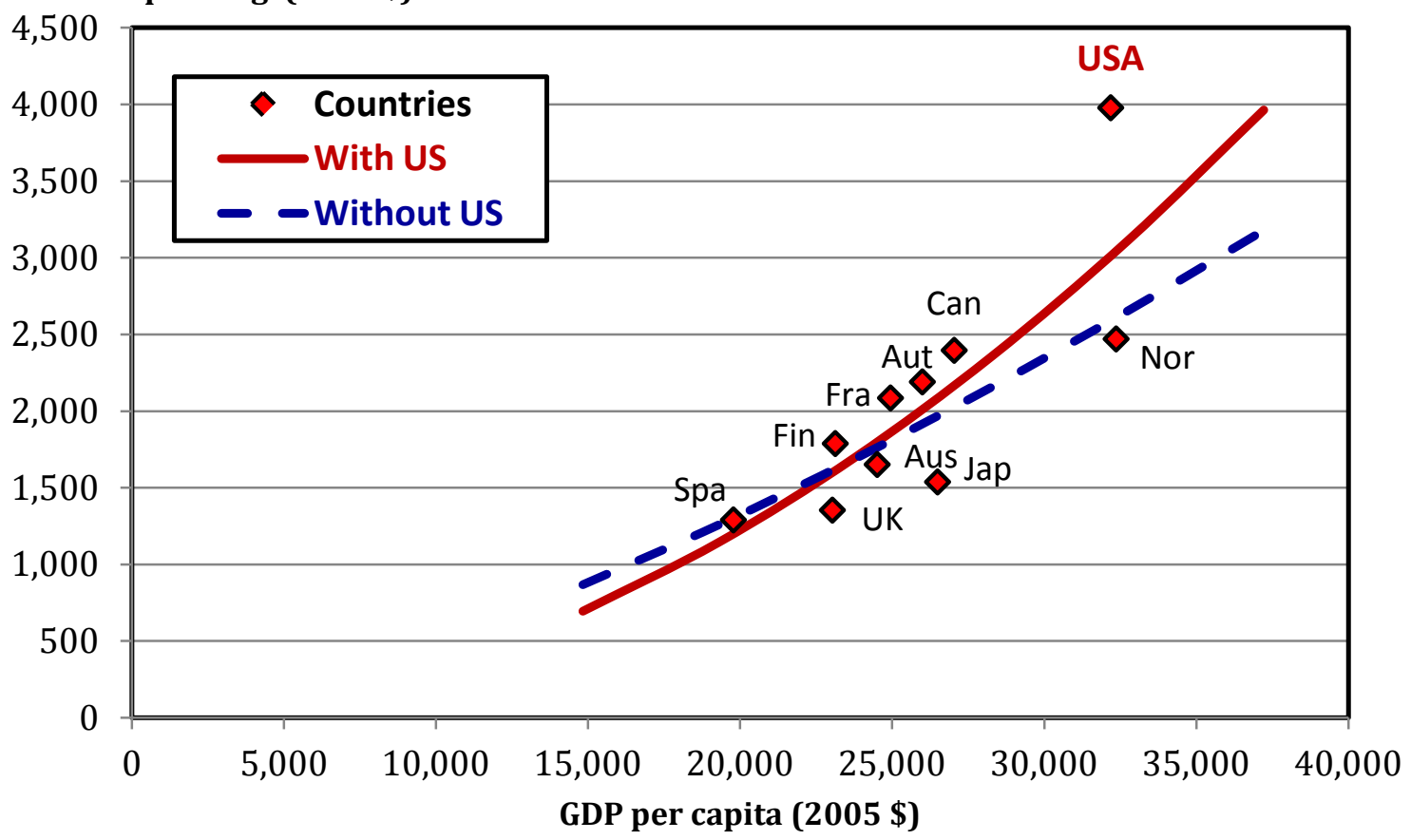

Health care spending per capita and GDP per capita in 2009

Health spending (2005 \$)

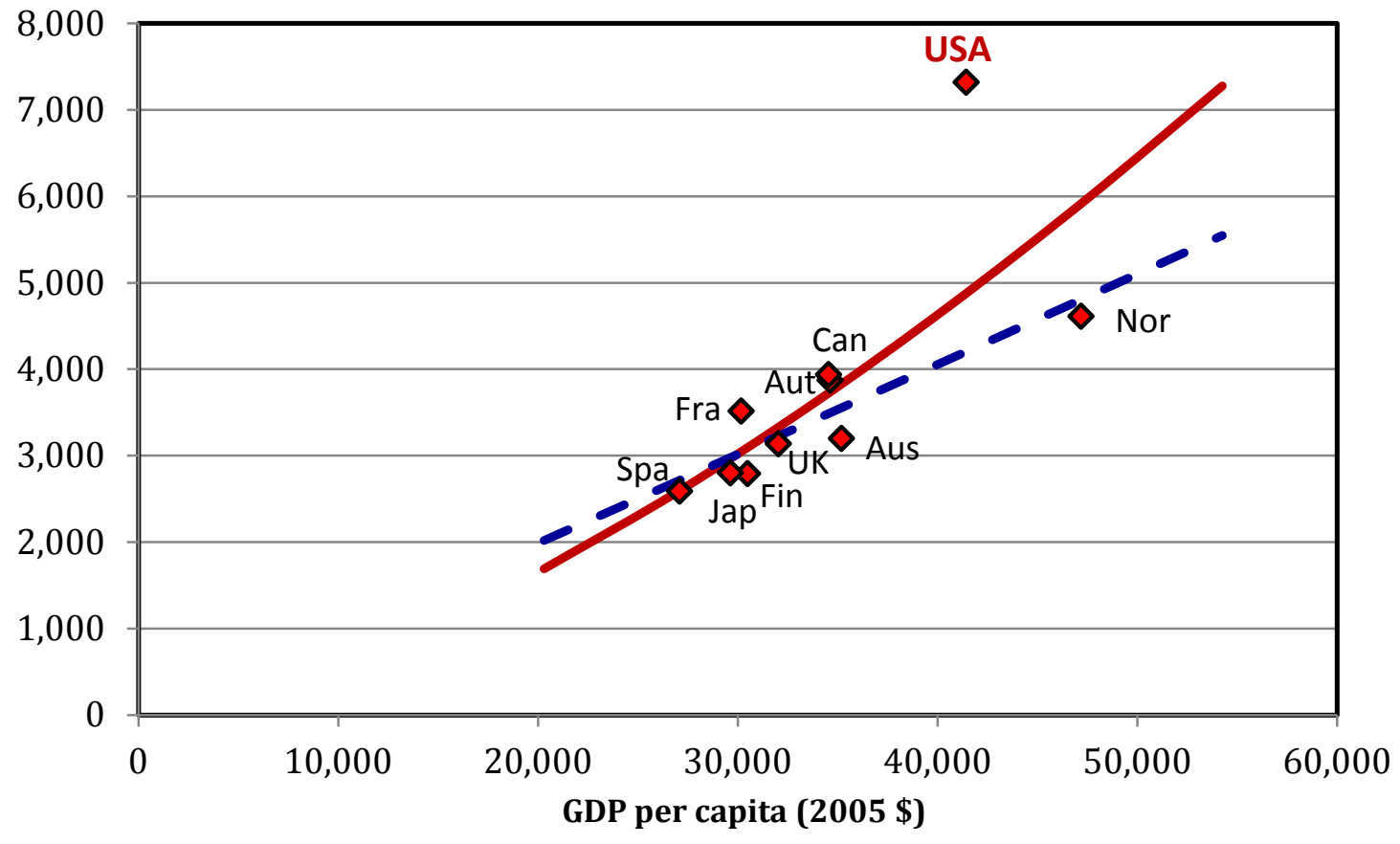

Source: Authors' calculations as explained in text. 
Figure 5. Annual Cross-National Estimates of Income Elasticity of Health Spending, with and without U.S. Included in Estimation, 1960-2009

Estimated income elasticity of health spending

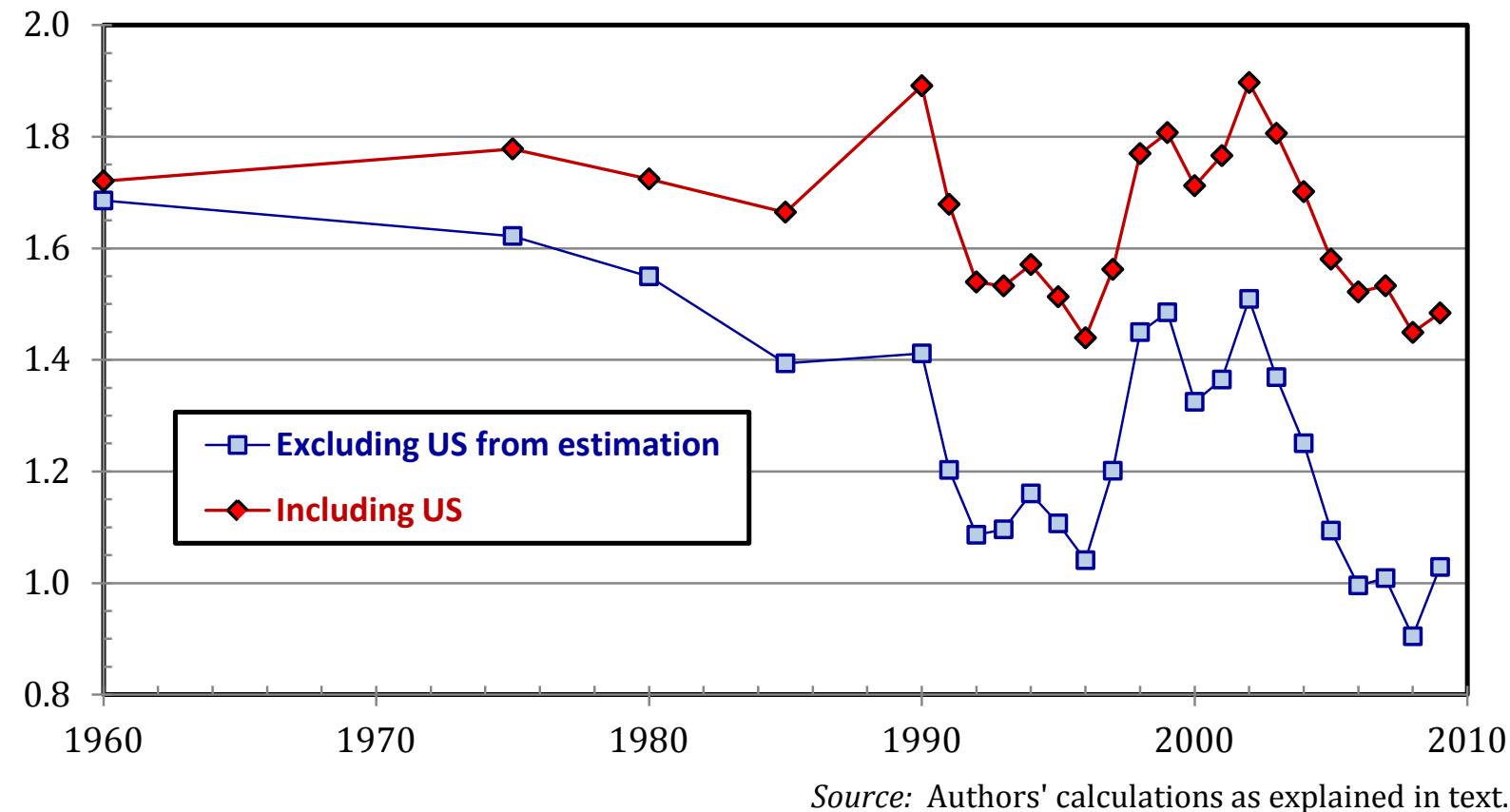

Figure 6. Estimates of Excess U.S. Health Spending Based on Country Cross-Section Estimates of Health Expenditure Function, 1960-2009

Excess spending as \% of predicted U.S. spending

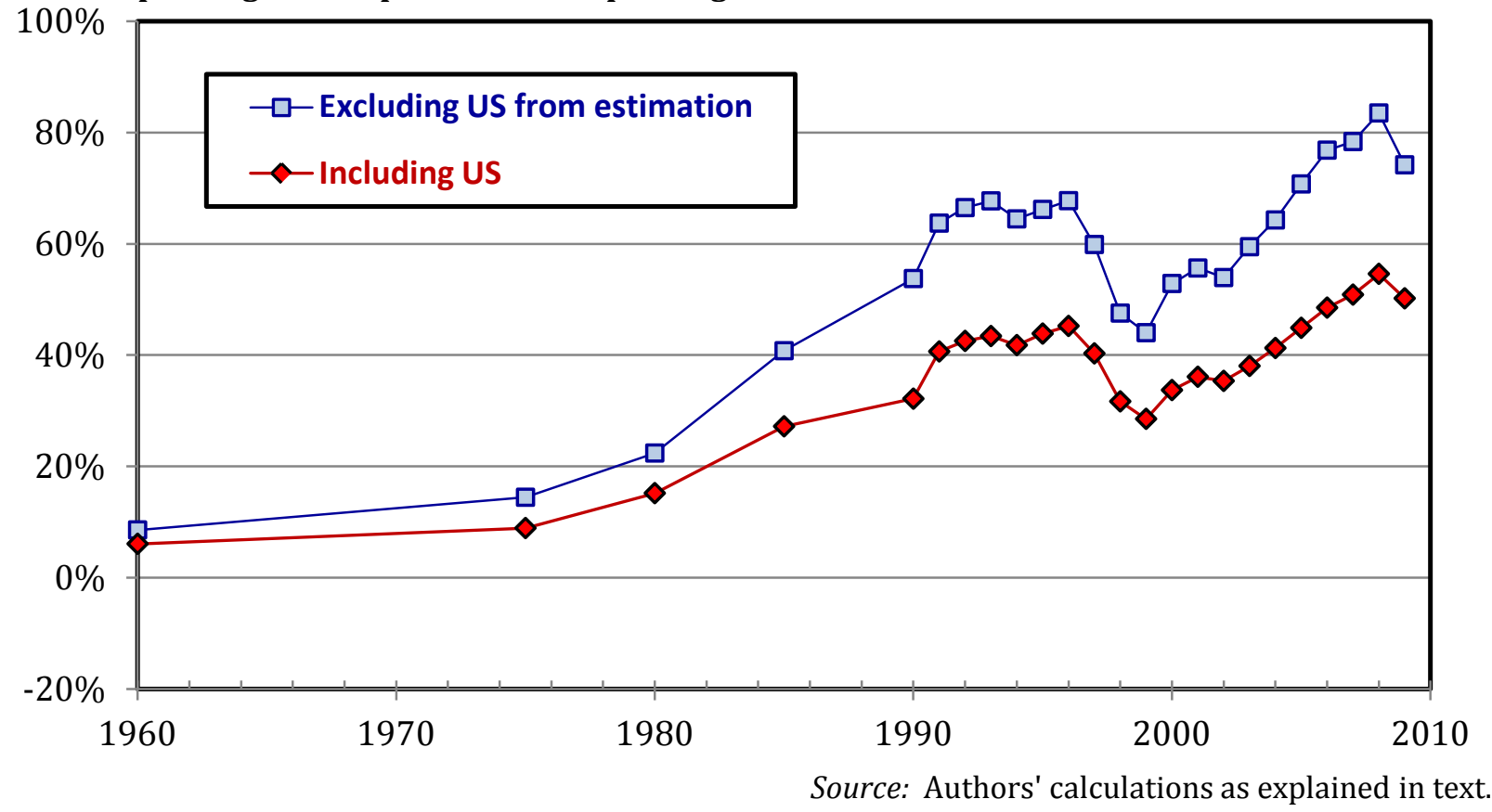


Figure 7a. Estimates of Excess U.S. Health Spending Based on Country Cross-Section Estimates of Health Expenditure Function, 1960-2010

Excess spending as \% of predicted U.S. spending in 21 countries

(Logarithmic specification)

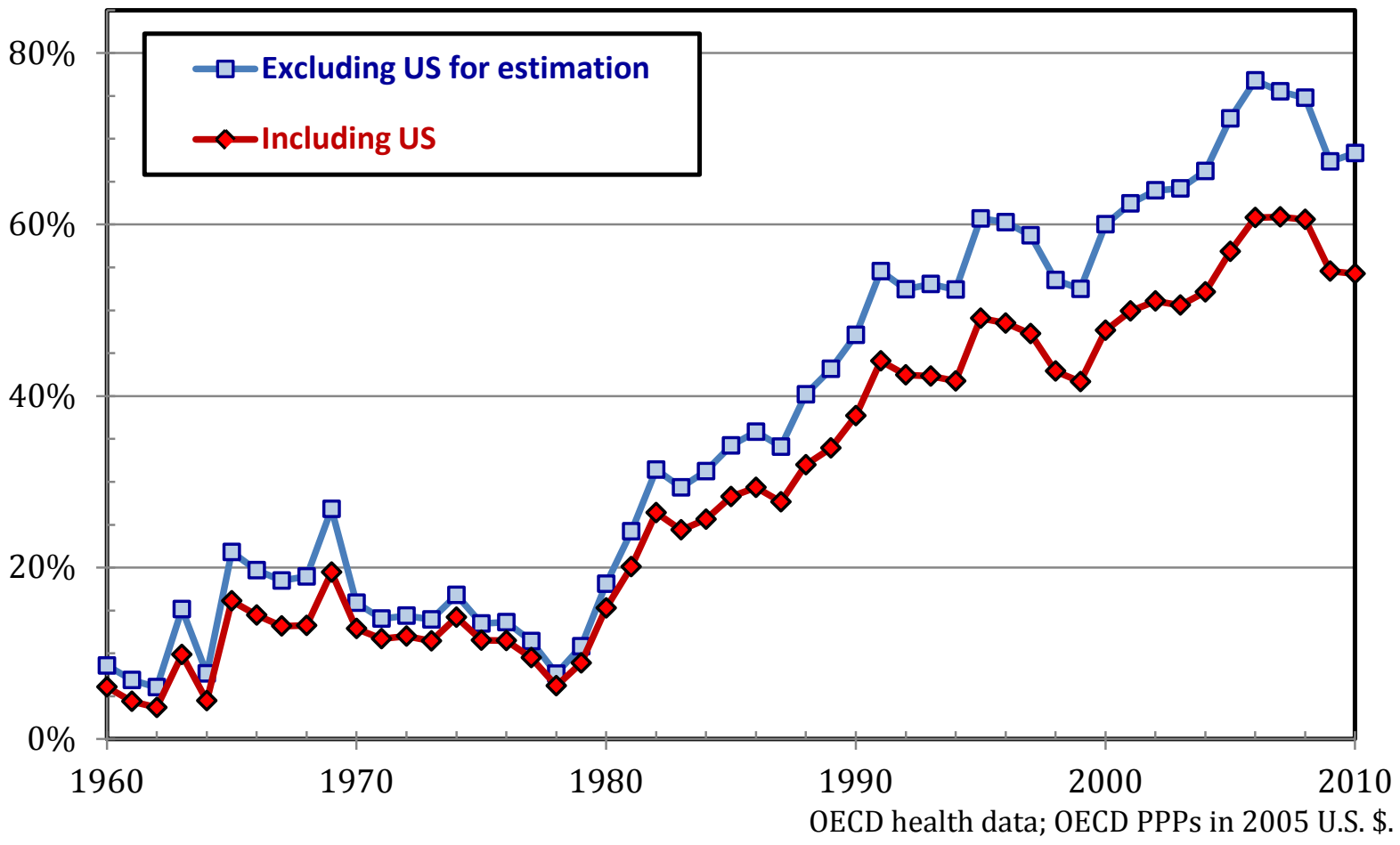

Excess spending as \% of predicted U.S. spending in 21 countries (Logarithmic specification)

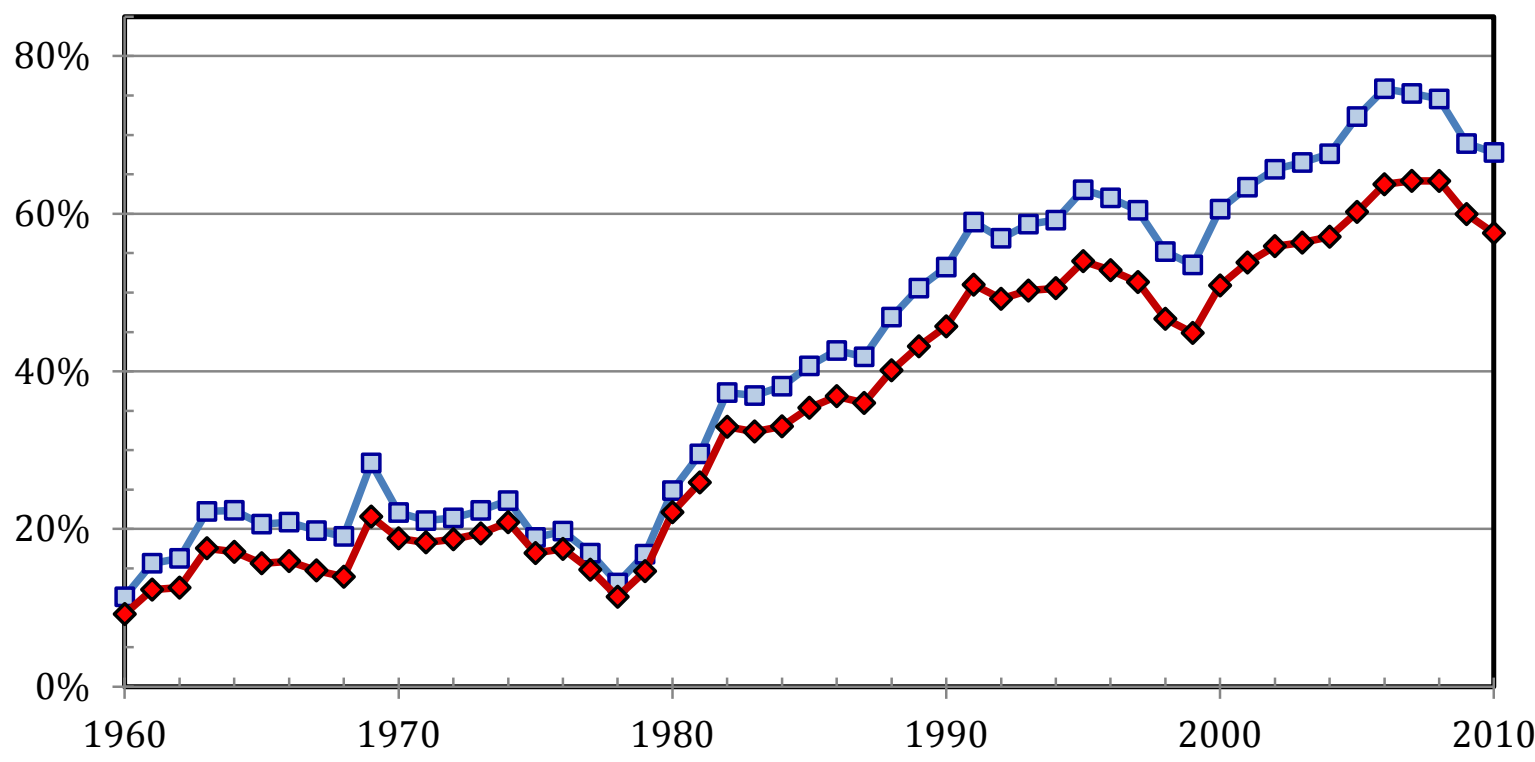

OECD health data; Penn World Tables, PPPs in 2005 U.S. \$. 
Figure 7b. Estimates of Excess U.S. Health Spending Based on Country Cross-Section Estimates of Health Expenditure Function, 1960-2010

Excess spending as \% of predicted U.S. spending in 17 countries

(Logarithmic specification)

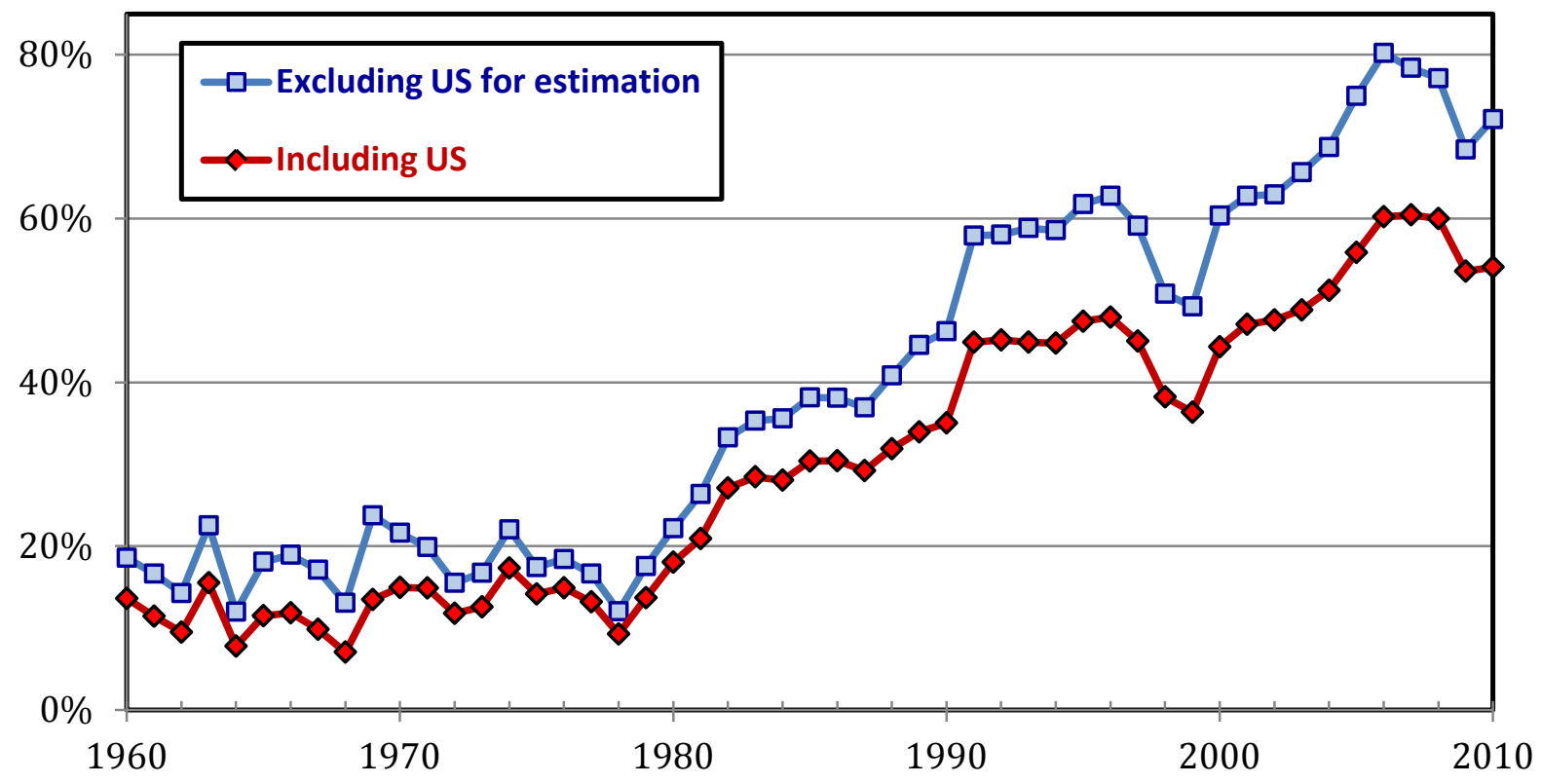

OECD health data; BLS PPPs in 2010 U.S. \$. 
Figure 8. Estimates of Excess Canadian Health Spending Based on Country Cross-Section Estimates of Health Expenditure Function, 1960-2010

\section{Excess spending as \% of predicted Canadian spending}

(Logarithmic specification)

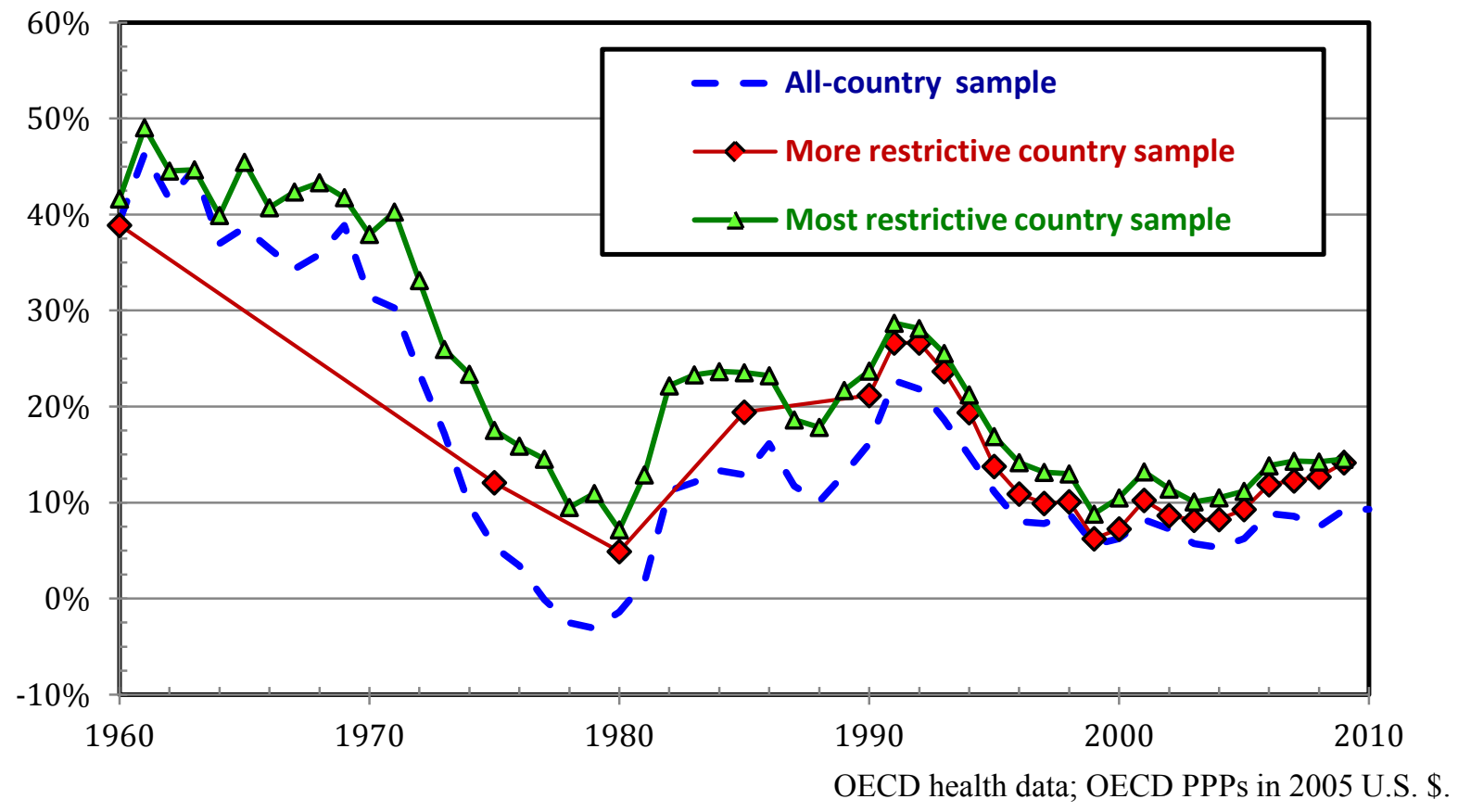

Excess spending as \% of predicted Canadian spending (Logarithmic specification)

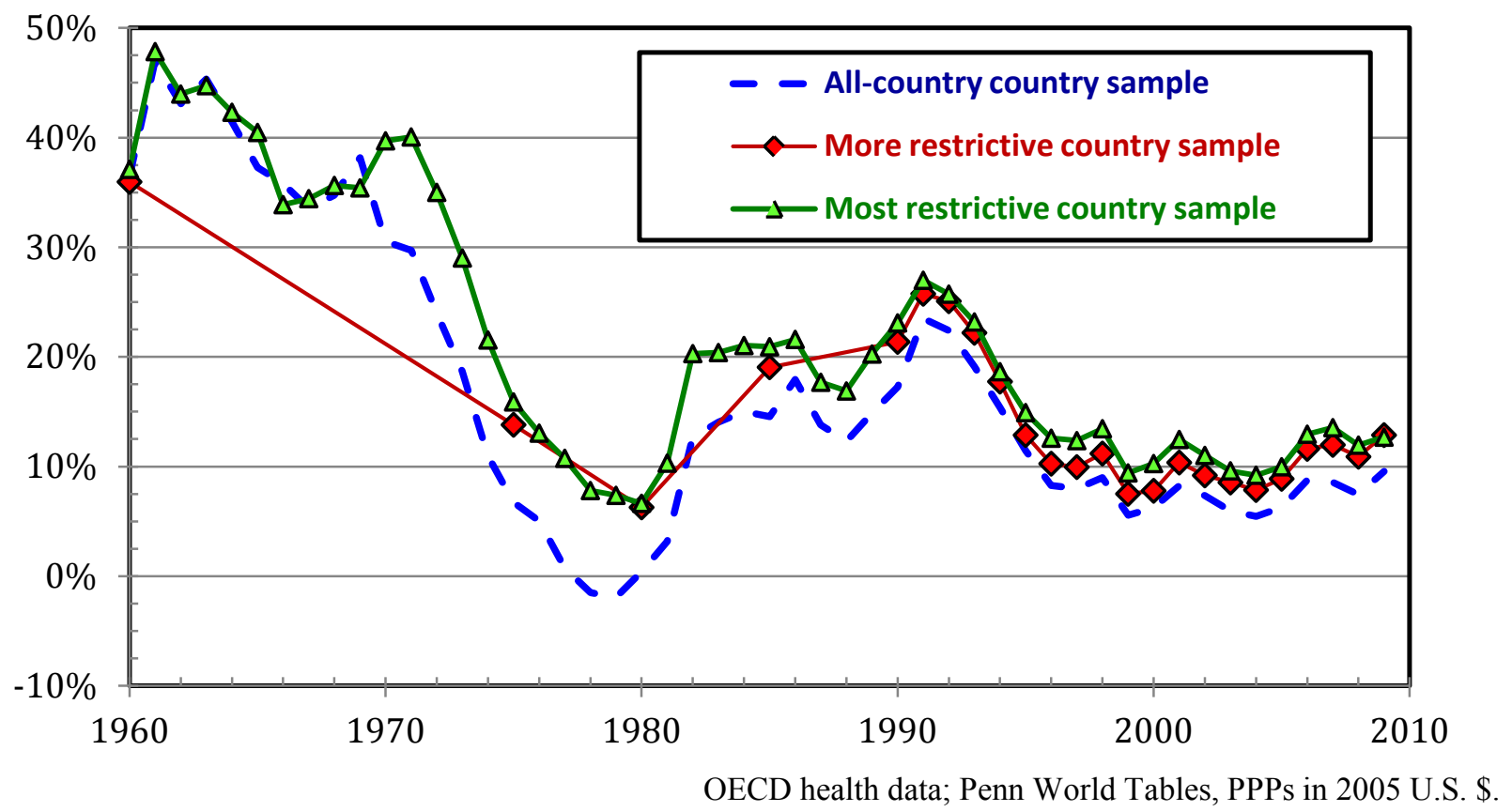


Figure 9. Rolling Average of Five-Year Growth in Per Capita Health Expenditures, 19722010

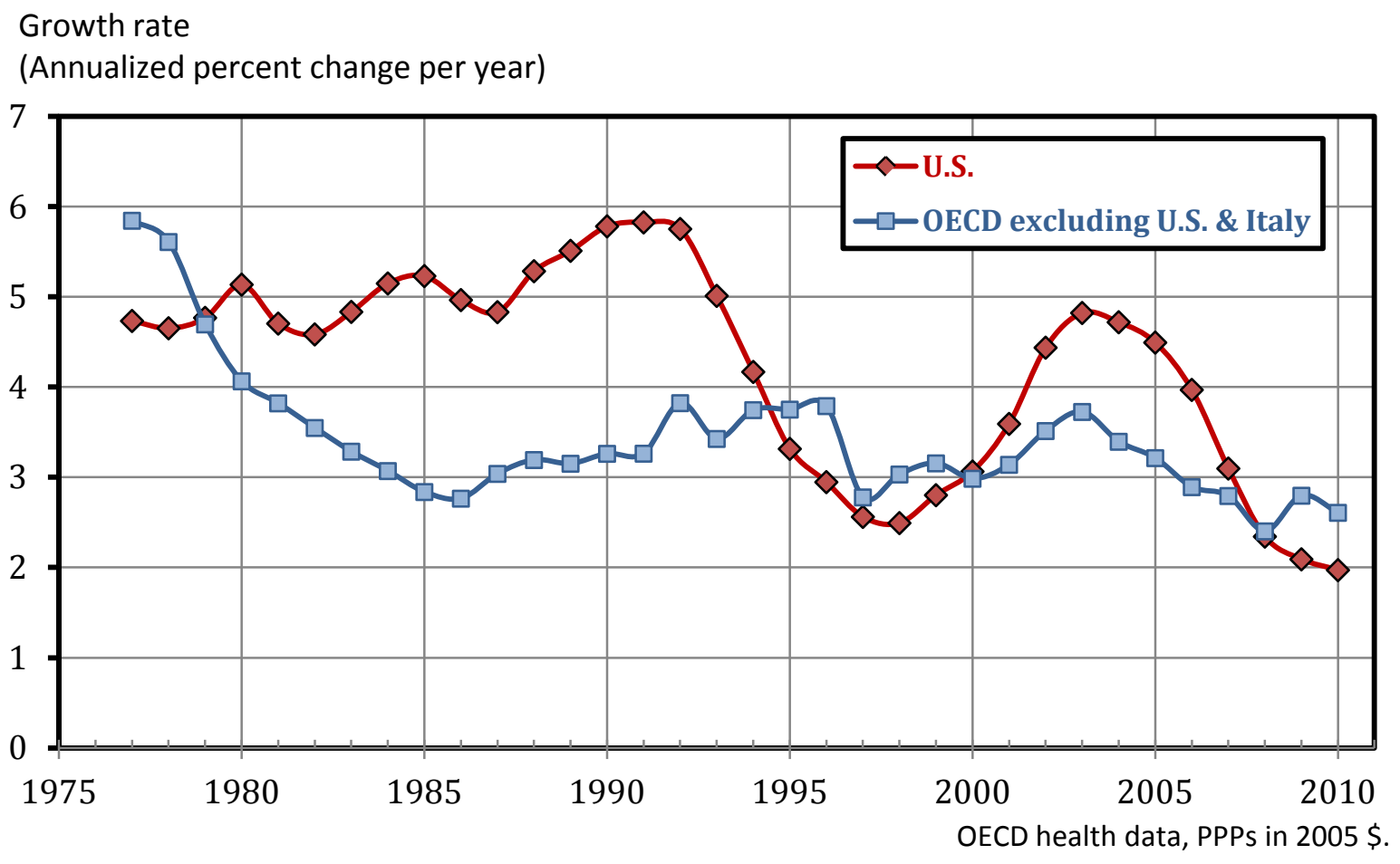




\section{RECENT WORKING PAPERS FROM THE CENTER FOR RETIREMENT RESEARCH AT BOSTON COLLEGE}

Using Participant Data to Improve 401(k) Asset Allocation

Zhenyu Li and Anthony Webb, September 2012

Job Demand and Early Retirement

Sepideh Modrek and Mark R. Cullen, August 2012

Changes in Labor Force Participation of Older Americans and Their Pension Structures: A Policy Perspective

Frank W. Heiland and Zhe Li, July 2012

How Would GASB Proposals Affect State and Local Pension Reporting?

Alicia H. Munnell, Jean-Pierre Aubry, Joshua Hurwitz and Laura Quinby, June 2012

Borrow Less Tomorrow: Behavioral Approaches to Debt Reduction

Dean Karlan and Jonathan Zinman, May 2012

Spousal Labor Market Effects from Government Health Insurance: Evidence from A Veterans Affairs Expansion

Melissa A. Boyle and Joanna N. Lahey, April 2012

Measuring Social Security Proposals by More than Solvency: Impacts on Poverty, Progressivity, Horizontal Equity, and Work Incentives

Melissa M. Favreault and C. Eugene Steuerle, April 2012

How Important Is Asset Allocation to Financial Security in Retirement?

Alicia H. Munnell, Natalia Sergeyevna Orlova, and Anthony Webb, April 2012

Great Recession-Induced Early Claimers: Who Are They? How Much Do They Lose?

Matthew S. Rutledge and Norma B. Coe, April 2012

Effects of Employer Health Costs on the Trend and Distribution of Social Security-Taxable Wages

Gary Burtless And Sveta Milusheva, April 2012

Should Households Base Asset Decumulation Strategies on Required Minimum Distribution Tables?

Wei Sun and Anthony Webb, April 2012

Geographic Mobility Among Residents in Seniors Housing and Care Communities:

Evidence from the Residents Financial Survey

Norma B. Coe and April Yanyuan Wu, April 2012

All working papers are available on the Center for Retirement Research website (http://crr.bc.edu) and can be requested by e-mail (crr@bc.edu) or phone (617-552-1762). 